NBER WORKING PAPER SERIES

\title{
PROTECTION OF MINORITY SHAREHOLDER INTERESTS, CROSS-LISTINGS IN THE UNITED STATES, AND SUBSEQUENT EQUITY OFFERINGS
}

\author{
William A. Reese, Jr. \\ Michael S. Weisbach \\ Working Paper 8164 \\ http://www.nber.org/papers/w8164 \\ NATIONAL BUREAU OF ECONOMIC RESEARCH \\ 1050 Massachusetts Avenue \\ Cambridge, MA 02138 \\ March 2001
}

We would like to thank Jack Coffee, Rafael La Porta, Saul Levmore, Amir Licht, Julio Lugo, Paul Meskiewicz, Darius Miller, Roberta Romano, Vijay Singal, Elliott Weiss, Marc Zenner, Rene Stulz, Jim Hsieh, Stephen Foerster, Florencio Lopez-De-Silanes, two anonymous referees, and seminar participants at Purdue, Texas, Virginia Tech, the Western Finance Association Meetings, the European Financial Management Association Meetings, and the Financial Management Association Meetings for helpful comments. The NSF (Grant SBR-9616675) provided financial support. The authors can be reached at William.Reese@tulane.edu and Weisbach@uiuc.edu. The views expressed herein are those of the authors and not necessarily those of the National Bureau of Economic Research.

(C) 2001 by William A. Reese, Jr. and Michael S. Weisbach. All rights reserved. Short sections of text, not to exceed two paragraphs, may be quoted without explicit permission provided that full credit, including $($ ) notice, is given to the source. 
Protection of Minority Shareholder Interests, Cross-listings in the United States, and Subsequent Equity Offerings

William A. Reese, Jr. and Michael S. Weisbach

NBER Working Paper No. 8164

March 2001

JEL No. G3, F3

\begin{abstract}
This paper examines the hypothesis that non-U.S. firms cross-list in the United States to increase protection of their minority shareholders. Cross-listing on an organized exchange (NYSE or Nasdaq) in the U.S. subjects a non-U.S. firm to a number of provisions of U.S. securities law and requires the firm to conform to U.S. GAAP. It therefore increases the expected cost to managers of extracting private benefits, and commits the firm to protecting minority shareholders' interests. The expected relation between the quantity of cross-listings and shareholder protection in the home country is ambiguous, because managers will consider both expected private benefits and the public value of their shares. However, there are clear predictions about the relation between subsequent equity issues, shareholder protection and cross-listings:
\end{abstract}

1) Equity issues increase following all cross-listings, regardless of shareholder protection.

2) The increase should be larger for cross-listings from countries with weak protection.

3) Equity issues following cross-listings in the U.S. will tend to be in the U.S. for firms from countries with strong protection and outside the U.S. for firms from countries with weak protection.

We find strong evidence supporting predictions 1) and 3), and weak evidence consistent with hypothesis 2). Overall, the desire to protect shareholder rights appears to be one reason why some non-U.S. firms cross-list in the United States. However, it probably is not an important determinant of the large recent increase in cross-listings, because legal requirements potentially deter a number of firms that do have a demand for equity capital from cross-listing in the U.S.

William A. Reese, Jr.

Tulane University

William.Reese@tulane.edu
Michael S. Weisbach

University of Illinois

and NBER

Weisbach@uiuc.edu 


\section{Introduction.}

An implicit but often unrecognized part of any financial contract is the ability of a legal system to enforce it. The quality of legal protection affects the ability of parties to expropriate resources from one another ex post, and thus influences the contracts that will be observed ex ante. Differences across countries in the quality of protection they provide claimholders should, by this logic, lead to observable differences in financial contracting. In fact, recent empirical work has documented that such international contracting differences exist and are substantial (see in particular La Porta et al. (1997, 1998)). These papers document that in countries where legal protections for minority claimholders are weak, it is considerably more difficult for a firm to raise external capital than for a similar firm in a country that protects minority interests well.

Coffee (1999a) and Stulz (1999) argue that a natural response to this potential expropriation problem by firms wishing to raise capital is for them to bond themselves to protect the interests of their minority stockholders. One way to accomplish this bonding is for them to cross-list on an organized exchange (NYSE or Nasdaq) in the United States, whose legal system protects minority shareholder interests as well as any in the world. Such a cross-listing obligates the firm to conform to U.S. GAAP, to file reports with the U.S. Securities and Exchange Commission, to comply with the requirements of the exchange on which it lists, and at least to some extent subjects the firm to U.S. securities laws. It thus provides a mechanism by which foreign firms can voluntarily subject themselves to at least some shareholders' protections under U.S. securities laws. For firms that might wish to have access to U.S. capital markets without the voluntary bonding, the OTC market (also known as the Pink Sheets), and Portal (the market for firms issuing equity under rule 144a) provide such an opportunity.

In this paper, we examine whether such voluntary bonding at least partially explains the recently observed rise in cross-listings. ${ }^{1}$ We first develop a number of hypotheses about the relations between cross-listings, shareholder protection and equity offerings. A manager considering cross-listing his firm's

\footnotetext{
${ }^{1}$ Between 1984 and 1993, 496 foreign firms chose to cross-list in the U.S. During the 1994 - 1998 period, 1435 cross-listings took place, almost three times as many in half as many years.
} 
stock in the U.S. when such a cross-listing has potential implications for shareholder protection must balance his expected change in private benefits with the expected change in shareholder protection, in addition to the more traditional benefits of cross-listing, including overcoming the obstacles of segmented markets [Stulz (1981), Errunza and Losq (1985)], or the problem of investor recognition [Merton (1987)]. The expected relation between cross-listings and shareholder protection is therefore theoretically ambiguous. However, the predictions regarding equity issues are clear. Equity issues should increase following all cross-listings, and the increase should be larger when the cross-listing increases shareholder protection. In addition, equity issues following cross-listings in the U.S. that do not change shareholder protection should be primarily in the U.S. while equity issues following cross-listings that increase shareholder protection should occur in all countries.

We examine these hypotheses using a database of cross-listing firms and their history of equity issues. We first consider the relation between cross-listings and shareholder protection. Univariate statistics suggest that firms with weak protection at home are more likely to cross-list; however, when we control for other factors such as firm size, this relation is reversed and cross-listings are more common from firms with strong protection at home. We find a large increase in both the number and value of equity offerings following a cross-listing, and find some evidence that firms with weak shareholder protection at home tend to issue larger quantities of equity following their cross-listing.

As a direct test of the bonding arguments, we separate the subsequent equity issues of cross-listed firms by location. We do so because the market segmentation and investor recognition arguments imply that foreign firms will cross-list in the U.S. to access American investors, and thus will tend to raise a significant portion of their future equity capital in the U.S. Conversely, the bonding argument implies that firms from countries with weak shareholder protection do not cross-list in the U.S. primarily to gain access to American investors, but to facilitate future offerings at home or elsewhere around the world. Consistent with these arguments, we find that firms from countries with strong protection for minority shareholders are more likely to issue subsequent equity in the U.S., while firms from countries with weak shareholder protection laws are more likely to issue subsequent equity outside the U.S. 
Overall, the desire to protect shareholder rights appears to be one reason why some non-U.S. firms cross-list in the United States. Cross-listing, though, reduces expected private benefits and thus comes at a potentially large cost to managers. The overall effect on cross-listings is unclear. When firms have a large demand for equity capital, we observe cross-listings providing a way to commit to protect shareholders' interests. However, it is unlikely that such bonding explains much of the overall rise in cross-listings in the U.S., because the expected loss of private benefits probably deters a number of firms from cross-listing that otherwise would have.

The remainder of the paper is structured as follows: Section 2 describes the mechanics of crosslisting and provides a short summary of the cross-listing literature. Section 3 discusses why different legal systems vary in their protection of minority shareholders and explains how cross-listing in the U.S. has implications for the protection of shareholder rights outside the U.S. Section 4 provides an intuitive discussion of the expected empirical relations between cross-listings, shareholder protection, and equity offerings. Section 5 describes how we constructed the sample used in the empirical analysis. Section 6 presents empirical results characterizing cross-listing behavior and its relation to shareholder protection in the country of origin. Section 7 discusses the empirical results about equity offerings subsequent to crosslistings and their relation to shareholder protection in the home country, while Section 8 concludes.

\section{Cross-listings}

\subsection{The Mechanics of Cross-Listing}

There are two ways that a foreign firm can choose to cross-list its shares on a U.S. exchange. It can either list its shares directly, or use American Depositary Receipts (ADRs). ADRs are negotiable certificates that represent a foreign company's publicly traded equity or debt. Sponsored ADRs are created when, at the request of the company, an American broker purchases the company's shares on its 
home stock market and delivers them to a "custodian" bank. ${ }^{2}$ The custodian bank issues Depositary Receipts, which trade freely either on an organized exchange, over the counter, or on Portal. ${ }^{3}$

While the vast majority of foreign firms choose to cross-list their stock through the use of ADRs, some firms (primarily Canadian and Israeli) choose to list their equity directly on a U.S. exchange. ${ }^{4}$ The listing and reporting requirements for firms with direct cross-listings are the same as for firms with an ADR. Therefore, we examine both ADRs and direct cross-listings in this paper.

Cross-listing in the United States substantially increases the disclosure and regulatory costs a company faces. If a foreign firm is cross-listed on an organized exchange, the firm must conform to U.S. GAAP and complete all required filings with the SEC. However, firms that choose to cross-list using the Over the Counter "Pink Sheets" or Rule 144a, are generally exempt from these requirements. ${ }^{5}$ The Federal Reporting Requirements are summarized in Table 1 Panel A. Additionally, there are three categories of requirements for listing that are imposed by the individual exchanges: Quantitative Standards, Corporate Governance Standards, and Financial Requirements. These are summarized in Panels B, C and D of Table 1. This table clearly indicates that there are essentially no Federal reporting or exchange requirements for OTC or 144a listings, while the requirements for NYSE and Nasdaq are fairly stringent.

Thus, at least to some extent, these accounting and reporting requirements can be thought of as voluntary, since the OTC and Portal markets provide firms with the accessibility to U.S. investors associated with a cross-listing without imposing these requirements. In fact, these requirements can have

\footnotetext{
${ }^{2}$ Historically, there have also been "unsponsored" depositary receipts, which were set up without the cooperation of the company. However, no unsponsored ADRs have been set up since 1983 when, under rule 12g3-2(b), depositaries were required to obtain the permission of the issuing firm before they could set up an ADR.

${ }^{3}$ Throughout the paper, we consider NYSE and Nasdaq-AMEX as organized exchanges.

${ }^{4}$ Virtually all Canadian firms which choose to cross-list do so directly. The existence of the Multi-Jurisdictional Disclosure System along with the close regional proximity eliminates the need for ADRs.

${ }^{5}$ Rule 144a, adopted in 1990, allows institutions with assets exceeding \$100 million to trade privately-placed unregistered equities among themselves. Prior to April 4, 1998, foreign firms could also list their ADRs on the Over-the-Counter Bulletin Board under the same exemptions as the Pink Sheets. On that day, however, the SEC's Office of International Corporate Finance issued a directive requiring all foreign firms listed on the OTCBB to meet the same reporting requirements as NYSE and Nasdaq. At the time, there were several hundred cross listings on OTCBB. Most of them switched to the Pink Sheets, while some of them went to Nasdaq. Virtually none remained on the OTCBB.
} 
substantial ramifications; Coffee (1999a) emphasizes how, when Daimler-Benz made the decision to list its stock on the NYSE in 1993, it was forced to restate its earnings as a significantly lower amount subsequent to its cross-listing (which preceded its purchase of Chrysler).

\subsection{Why do Firms Cross-List?}

This paper examines the hypothesis that legal considerations provide one reason for cross-listing in the United States. However, the legal considerations are only one of a number of reasons why firms cross-list outside their home country. A number of other factors that affect cross-listings have been suggested by the literature and have received empirical support. ${ }^{6}$ These reasons are not mutually exclusive, and complement the legal explanations emphasized here.

\section{Market Segmentation/Investor Recognition}

One reason for cross-listing is that it allows investors to avoid cross-border barriers to investment. These barriers could be regulatory restrictions, direct costs, or information problems of a number of sorts, including uninformative accounting information, or simply not knowing about a security (Merton (1987)). Theories of capital market integration suggest that removing these barriers and integrating markets will allow for more efficient diversification and lower the risk of a given security. ${ }^{7}$ The two main predictions of this idea are that stock prices will rise in the home country in response to a cross-listing and that a firm's cost of capital will decline when a firm cross-lists its security. Each of these predictions has been tested extensively in the literature.

Switzer (1986), Alexander et. al. (1988), Foerster and Karolyi (1993, 1999), Jayaraman et. al. (1993), and Miller (1999) all examine the stock-price reaction when non-U.S. firms cross-list in the U.S. Though the results vary somewhat across samples, these studies generally find a small positive reaction to

\footnotetext{
${ }^{6}$ Karolyi (1998) provides an excellent summary of this literature. Also see Licht (2000) for a legal perspective on the cross-listings literature.

${ }^{7}$ Black (1974), Stapleton and Subrahmanyam (1977), Stulz (1981), Errunza and Losq (1985), Eun and Janakiramanan (1986) and Alexander et. al. (1987) provide contributions to the theory of capital market integration. Stulz (1999) gives an intuitive summary of capital market integration and implications for the cost of capital.
} 
the announcement (or the listing). This finding is consistent with the market segmentation hypothesis, as well as other explanations for cross-listing. ${ }^{8}$

A second implication of the market segmentation explanation for cross-listing is that the firm's cost of capital should decline following the cross-listing. A number of studies have estimated changes in the cost of capital after non-U.S. firms cross-list in the U.S [see Alexander et. al. (1998), Foerster and Karolyi (1993, 1999), Jayaraman et. al. (1993), Karolyi (1998), and Errunza and Miller (1999)]. These papers generally find that the cost of capital declines following a cross-listing, consistent with the view that at least one effect of the cross-listing is a decrease in market segmentation. Lins, Strickland and Zenner (1999) find that the investment to cash flow sensitivity of cross-listing firms decreases subsequent to the listing of an ADR on either the NYSE or Nasdaq by emerging market firms. This finding suggests that cross-listing has the effect of easing capital constraints for these firms.

Liquidity.

A decrease in transactions costs is another channel through which a cross-listing might be able to decrease a firm's cost of capital. There are a number of reasons why liquidity could improve following cross-listings. In particular, access to more investors could lead to higher volume, information asymmetries could decrease due to increased disclosure, and there could be exchange-specific reasons why transactions costs might be lower in the U.S. than in the home country. Tinic and West (1974), Foerster and Karolyi (1998), Domowitz et. al. (1998), and Smith and Sofianos (1997) all examine the effect of cross-listing in the U.S. on the costs of transacting a particular security. These papers generally find that spreads decrease and trading volume increases following a cross-listing, both of which will likely reflect an increase in liquidity. Bacidore and Sofianos (2000) however, find that non-U.S. stocks which are traded on the NYSE have wider spreads than domestic stocks. So while a cross-listing may increase a foreign firm's liquidity, it is likely to nonetheless be less liquid than a comparable firm that is domiciled in the U.S.

\footnotetext{
${ }^{8}$ These studies also document that there is a substantial negative abnormal stock return over the year subsequent to the cross-listing.
} 


\section{Commitment to Reveal Information.}

In the models of Cantale (1998) and Fuerst (1998), stock prices rise when firms list on exchanges with higher disclosure standards. The idea is that cross-listing commits managers to a policy of better disclosure and hence reduces managers' expected future private benefits. Moel (1999) estimates a model predicting the exchange on which firms choose to cross-list, conditional on cross-listing in the U.S. His empirical results are generally consistent with a model in which firms cross-list as a way of bonding themselves to subsequent information releases. Huddart, Hughes and Brunnermeier (1999) formalize the notion that exchanges competing for trading volume engage in a 'race for the top' in terms of disclosure requirements. Consistent with this notion is empirical evidence in Pagano, Roel and Zechner (1999) documenting that the increase in cross-listings in recent years is largest for exchanges with the highest disclosure requirements. Together, these papers suggest that firms from countries with poor investor protection clearly have incentives to cross-list as a way of committing to high disclosure.

\section{Protection of Minority Shareholder Interests}

\subsection{Legal Systems and Protection}

Different countries' legal systems have evolved in a number of ways, falling into two main categories: common law and civil law. Common law originated in England and spread to most of the former English colonies and to a number of other countries. The evolution of common law depends on decisions made by judges, which are subsequently incorporated into written law by the legislature. In contrast, the civil legal tradition, which began with Roman law, relies on statutes and comprehensive legal codes. Civil law has evolved in three separate but related ways, which we label French, German, and Scandinavian Civil Law.

An important difference between the two systems is the role of the judge and the concept of fiduciary duty (see Coffee 1999b). Under civil law, judges are required to mechanically apply comprehensive codes to the cases before them. If a new issue that is not specifically covered in an existing code comes before the court, the judge has little discretionary power to deal with it, regardless of 
the judge's opinions on the matter. In contrast, common law courts rely on the concept of fiduciary duty, which gives judges much greater discretion in issues involving shareholder rights. Common law judges appear to be prone towards applying this discretion in favor of minority shareholders, especially when the existing statutes do not specifically directly address an issue the judge is considering.

There are important differences in laws between countries of the same legal origin [see Coffee (1999b)]. Nonetheless, La Porta et. al (1998) find that the legal tradition is an important factor in determining the nature and enforcement of the laws. Most countries fall into one of the categories discussed here: English Common Law, French Civil Law, German Civil Law, or Scandinavian Civil Law. Table 2 includes a listing of the countries that fall into each of these categories.

Recent work has suggested that legal tradition affects both the explicit laws protecting minority shareholder rights and the net effect of these laws on corporations' ability to receive financing (See La Porta et. al. (1997, 1998, 2000)). In particular, these papers document that countries using English Common Law protect minority shareholders' rights better than those with civil law traditions. Within the civil law countries, French Civil Law provides significantly less protection for shareholders, while the German and Scandinavian traditions provide an intermediate level of protection. In addition, these papers document that these protections lead firms to have easier access to capital and more subsequent external financing. ${ }^{9}$

\subsection{Legal Requirements and Cross-Listings}

The requirements associated with registering with the SEC are substantially greater than disclosure and reporting. U.S. securities laws affect companies that choose to cross-list in a number of ways that inhibit potential agency problems resulting from large shareholder/small shareholder conflicts. Coffee (1999a) details six provisions of U.S. securities laws that go well beyond those typically found overseas in the degree to which they aid small shareholders (pp. 683-691):

\footnotetext{
${ }^{9}$ Rajan and Zingales (1999) dispute this argument, claiming that the differences in shareholder protections observed between countries are caused by political differences rather than different legal systems. For our purposes, this debate is moot; all that is relevant is that the differences in shareholder protections exist.
} 
1) Section 13(d) of the Securities Exchange Act of 1934 requires any person or group beneficially owning at least $5 \%$ of any equity security to file a report within five days of when the $5 \%$ threshold is crossed. This $5 \%$ threshold is noticeably smaller than the $10 \%$ that is required by the European Community's Transparency Directive and clearly has a large impact on takeover strategies and their implications for small shareholders [see Shleifer and Vishny (1986), p. 477 for example].

2) Under Section 14(d) of the Exchange Act, all tender offers for corporations registered with the S.E.C. have to comply with U.S. disclosure and procedural rules. These rules would apply if one European company makes an offer for a second European company that has an ADR in the U.S., even if the shares traded in the U.S. amount to less than one percent of the outstanding shares. An important aspect of these procedural rules is that each shareholder of a particular class has the right to participate in any tender offer and to receive the best price paid to any other shareholder pursuant to the tender offer. Registering in the U.S. thus substantially increases the rights of shareholders of non-U.S. firms when faced with a tender offer.

3) Firms cross-listing on a U.S. exchange are subject to most of the rules of the exchange regarding corporate governance. [See Table 1]

4) The S.E.C. is granted authority under Section 13(e) of the Exchange Act to regulate the treatment of minority shareholders in "going private" transactions. The impact of this provision, according to Coffee (1999a), is to "deny controlling shareholders the practical ability to squeeze out the minority at an unfairly low price."

5) Under the Foreign Corrupt Practices Act, all registered U.S. corporations are required to keep books and records that fairly reflect the transactions of the issuer. The purpose of this law is to prevent corporations from engaging in bribery or similar practices.

6) Rule 10b-5 gives shareholders the right to sue for losses ensued because of fraudulent statements made by a company whose equity they own. Listing in the United States subjects foreign companies to this rule, and allows them to be sued in the United States for fraudulent statements made anywhere in the world. Only U.S. investors can sue under this rule, but all investors are likely to benefit from it because of the disincentives it provides for managers to release fraudulent information. ${ }^{10}$

\footnotetext{
${ }^{10}$ Of course, for plaintiffs to collect on such a suit, the firm has to have some assets in the United States. A firm without assets in the U.S., however, would presumably find it costly to have a judgement against it in the U.S., and thus the potential for such a judgement would provide incentives for managers ex ante.
} 
The impact of these laws is mitigated somewhat by the fact that the S.E.C. is probably less likely to prosecute foreign companies than U.S. ones, and by any potential future decisions that limit the degree to which these rules apply to foreign companies. Still, it seems clear that any foreign manager choosing to list stock on a U.S. exchange should expect that such a listing will reduce his ability to expropriate wealth from minority shareholders. Likewise, it seems plausible that the concerns of prospective shareholders of foreign companies about wealth expropriation should be at least partially alleviated by the company's listing in the U.S., even if they intend to purchase the stock on a foreign exchange. Thus, the existence of the protections that come from cross-listing securities on an organized U.S. exchange is one of a number of explanations for why establishing a depositary receipt program is associated with a stockprice increase in the home country.

\section{Legal Protections, Cross-Listings, and Implications for Data}

To evaluate empirically the importance of legal issues in the cross-listing decision, one must first understand the empirical implications of the incremental shareholder protection associated with a crosslisting. With this in mind, suppose that cross-listing in the United States provides some extra protection for minority shareholders. Given this assumption, what should one expect to observe in the data? In particular, how should cross-listing behavior, the level of legal protection, and capital-raising activity be related?

A firm will choose to cross-list its stock when the benefits of cross-listing outweigh the associated costs. Absent legal considerations, the costs of cross-listing are primarily the monetary cost of listing together with the increased disclosure costs. Denote the present value of these costs as $C_{N L}$. The present value of non-legal benefits from cross-listing, $B_{N L}$, result from the potentially lowered cost of capital arising from decreased market segmentation and increased liquidity. These would vary over time, depending on the firm's demand for capital at that time. A firm will choose to cross-list, if at any point in time, the present value of the subsequent benefits are greater than the present value of the subsequent costs, i.e., whenever $B_{N L}>C_{N L}$. Note that $B_{N L}$ is likely to increase with a firm's high demand for external 
finance, while $C_{N L}$ is likely to be independent of external financing considerations. Therefore, even without legal considerations, we would expect to observe an increase in external financing subsequent to a cross-listing.

If a cross-listing changes the level of legal protection for minority shareholders, then this change will influence the desirability of a cross-listing to a manager. Presumably, a manager cares about both the private benefits he derives from managing the company, and the financial performance of his company. Changing the level of shareholder protection will affect both. Clearly, increased protection decreases the expected private benefits accruing to the firm's managers. Denote the present value of the change in private benefits associated with cross-listing as $\Delta$ PrivBen. In addition, changing shareholder protection will affect the public value of the company for two reasons: First, this decrease in expected private benefits increases the value of the firm's public stock directly because it lowers expected wealth transfers out of current cash flows as well as leading to an expected increase in efficiency. Second, it will increase total expected cash flows indirectly, by enabling managers to undertake more positive net present value projects. These extra projects are those for which financing is potentially available when the firm is bonded to protect minority shareholders but for which no financing was available without this bonding (or equivalently, available but at a sufficiently high cost of capital to make the project unattractive). Let the manager's personal valuation of these effects be denoted as $\triangle P u b V a l$.

Given this notation, a firm will choose to cross-list in the U.S. if:

$$
0<B_{N L}-C_{N L}+\Delta \text { PubVal }-\Delta \text { PrivBen }
$$

If cross-listing affects legal protection, then this effect should feed back and influence a manager's choice of whether to cross-list. In particular, when $\triangle P u b V a l-\triangle P r i v B e n$ is positive, the increase in shareholder protection is a net benefit to managers and, at the margin, increases the likelihood of a cross-listing. In contrast, when $\triangle P u b V a l-\triangle P r i v B e n$ is negative, the extra shareholder protection makes cross-listing undesirable to a manager whose expected private benefits will decline. 
To evaluate the sign of $\triangle P u b V a l$ - $\triangle P$ PrivBen, consider the two components of the increase in the public value of the firm's shares: the expected decrease in the wealth transfers from the managers, and the value created by projects that will be able to receive financing with the additional shareholder protection. The first of these factors, the decrease in wealth transfers, will always be worth less to the managers than the private benefits they receive from these transfers, because they keep all of the private benefits but share the costs of the transfers with other shareholders. However, if the extra value created by new projects is sufficiently large, then $\triangle P u b V a l$ potentially can be high enough to offset the loss in private benefits to the manager. These arguments suggest that when a potential cross-listing affects the legal protection for minority shareholders, extra protection will make cross-listing less attractive for firms with no demand for external finance, and make it more attractive for firms with high demand for external finance. This intuition is consistent with the results of Lombardo and Pagano's (2000) formal model, in which managers who cannot get external financing prefer increased legal protection but managers who currently have sufficient external financing do not.

In summary, this analysis suggests a number of implications for the data. First, the overall relationship between legal protection and cross-listings is theoretically ambiguous. Legal protection increases the public value of shares but decreases private benefits, so it is not clear which dominates. Second, for firms from all countries, even those with good shareholder protection at home, there should be an increase in equity financing subsequent to a cross-listing. Finally, additional legal protection for shareholders should increase the relation between cross-listing and subsequent equity financing. Incremental shareholder protection should lead to an increase in all subsequent equity issues, not just those done in the county the firm has cross-listed to. ${ }^{11}$ In contrast, when a firm has strong protection prior to the cross-listing, the increase in equity financing should occur primarily in the country the firm crosslists in.

\footnotetext{
${ }^{11}$ Consistent with this hypothesis, Pagano, Roell, and Zechner (1999) find that European firms cross-listing in the U.S. tend to increase in market value following the cross-listing (which is likely to be associated with increased protection), while those cross-listing in another European country (which is less likely to be associated with an increase in protection) tend to see their market value decline.
} 


\section{Sample Description}

We obtain a complete list of depositary receipts from the Bank of New York web site [www.adrbny.com]. This list provides the names, listing dates, country of origin, and exchange (NYSE, Nasdaq, OTC, or 144a) of every ADR and GDR as of June 1999. We obtain the same information on direct listings from the NYSE and Nasdaq websites and from the May 21, 1999 edition of the National Quotation Bureau's Pink Sheets. For the 42 firms that initially listed their depositary receipts OTC and "upgraded" to Nasdaq or the NYSE, we use the date of the upgrade.

Securities Data Corp. (SDC) provides information on new issues. SDC contains data on the date of issue, the market (country) in which the security was issued, and the proceeds from each issue. We compare the listing dates of the cross-listed firms with the issue dates of their new issues to determine the number of prior and subsequent equity offerings, their proceeds, and the country of issue.

The Bank of New York lists 2018 depositary receipts. Of those, 285 are from countries whose legal system does not fall into one of the four we are examining (most of these 285 ADRs are from Russia, China and Poland). ${ }^{12}$ We eliminate the 165 ADRs for which the Bank of New York does not list its exchange. Finally, we delete 267 unsponsored ADRs (113 of which are from Japan) from our sample since these companies are not cross-listed through their own choice. Only two ADRs are listed on AMEX, so to avoid a separate category for these two firms, we group them with the Nasdaq listings.

Because the legal implications of ADRs and direct cross-listings are the same, we also include direct cross-listings in our sample. As of June 1999, there were 107 firms that directly cross-listed on the NYSE without an ADR, 178 on Nasdaq, and 326 on the OTC pink sheets. Combining the direct crosslistings and ADRs, we end up with a sample of 1912 non-U.S. firms that were cross-listed in the U.S. in June 1999.

\footnotetext{
${ }^{12}$ Following La Porta et. al (1997, 1998), we exclude these countries because they were in a time of legal transition during our sample period.
} 
We obtain firm-specific information such as market value, earnings per share and dividends per share from Worldscope. Unfortunately, only 960 of the 1912 cross-listing firms have data available on Worldscope. Predictably, the firms with Worldscope data tend to be larger firms. ${ }^{13}$ In designing our tests, there is a tradeoff between sample size and data availability; using the entire sample allows for approximately twice as many observations as does the Worldscope subsample, but does not allow us to control for potentially important factors such as firm size and profitability. Our approach is to present the results both ways, first using the entire sample of 1912 cross-listing firms and, second, using the 960 firms for which we have firm-specific data on Worldscope.

\section{Cross-Listings by Country of Origin.}

\subsection{Univariate Differences}

Table 2 provides data on cross-listings by country of origin, separating the countries by their legal system. Panel A provides information on the firms from English Common Law countries, Panel B from French Civil Law countries, Panel C from German Civil Law countries and Panel D from Scandinavian Civil Law countries. Following La Porta et. al (1997, 1998), we focus on the differences between the French Civil Law and the English Common Law countries. There are two differences that are evident from this table. First, cross-listing is more common in French Civil Law Countries than in English Common Law countries. In the French Civil Law Countries $9.95 \%$ of publicly-traded firms have listings of some sort in the U.S., while from the English Common Law Countries, only $6.79 \%$ are cross-listed in the U.S. These percentages are different from each other at the $1 \%$ level.

Second, the firms from French Civil Law Countries appear to list disproportionately on organized exchanges, particularly the NYSE. Differences between organized exchange listings and OTC listings are important because organized exchange listings, unlike OTC and 144a listings, subject the firm to accounting and regulatory requirements, bonding them to protect shareholder interests. Of the 491 firms

\footnotetext{
${ }^{13}$ Interestingly, 380 of the 952 cross-listing firms that are not found in the Worldscope database are from Canada, probably because smaller Canadian firms are more likely to cross-list in the U.S. than similar firms from other
} 
from French Civil Law Countries that have cross-listed, $46.4 \%$ of them choose to list on an organized exchange. In comparison, of the 1180 firms from English Common Law countries that cross-list in the U.S., only $38.9 \%$ do so on an organized exchange. The difference in the percentage choosing to list on an organized exchange between and English and French countries is also significantly different from zero at the $1 \%$ level.

Combining these two effects, it is significantly more likely for a firm from a French Civil Law country to list on an organized U.S. exchange than one from an English Common Law country (4.62\% vs. 2.64\%). At first glance, this finding is suggestive that firms bond themselves to protect shareholder interests by listing in the United States. However, this evidence is somewhat weak for several reasons. First, there are clearly country-specific factors influencing this pattern. India, an English Law country, has over 7,000 listed firms but only one exchange-listed cross-listing. ${ }^{14}$ Canada and Israel, which have the largest number of direct cross-listings, represent almost $40 \%$ of all English Common Law cross-listings. ${ }^{15}$ Both of these countries have unusually strong cultural and business ties to the United States; if these ties provide additional reasons for cross-listing beyond those discussed above, the number of cross-listings for the English Common Law firms could potentially be inflated. ${ }^{16}$ Clearly, there are country-specific factors that have unusual effects on these results.

Second, German and Scandinavian Civil Law Countries do not appear to follow the pattern set by the English and French legal regimes. According to arguments in La Porta et. al, these countries should have an "in-between" level of cross-listing, since their shareholder protections are higher than French countries but lower than English ones. However, these countries do not appear to fit the overall pattern. German countries have the lowest level of cross-listing, while Scandinavian countries have the highest.

\footnotetext{
countries.

${ }^{14}$ If we remove India from the sample, the fraction of English Common Law firms listing on an organized exchange rises to $4.73 \%$, which is insignificantly different from the $4.62 \%$ of the French Civil Law firms listing on an organized exchange.

${ }^{15}$ None of Canada's cross-listings use depositary receipts, and seventy two percent of Israel's cross-listings are direct.

${ }^{16}$ Removing Canadian and Israeli direct cross-listings (non-ADRs) from the sample along with India, makes the difference between the French Civil Law firms and the English Common Law firms significant again.
} 
Even though these legal systems are substantially smaller than the English and French in terms of the number of countries they represent, these results are somewhat puzzling.

Finally, the univariate results do not control for other potentially relevant factors affecting crosslistings, such as firm size, and the country's GNP. We now use explicit measures of shareholder protection to gauge the extent to which these measures predict which firms are more likely to list on an organized exchange. In doing so, we are able to control for other factors that potentially affect crosslistings in a multivariate context.

\subsection{Multivariate Differences}

We consider three separate measures of shareholder protection in the home country of a crosslisting firm, which are obtained from La Porta et. al (1997,1998). The first determinant of shareholder protection is in fact the legal tradition of the home country (French, German or Scandinavian Civil Law, or English Common Law). Second, we use an index of "anti-director" rights, which measures the aggregate of six important shareholder rights in different countries. ${ }^{17}$ These two measures of shareholder protection are emphasized by La Porta et. al (2000) in their study of international dividend policies.

Additionally, since conforming to U.S. GAAP is an important requirement associated with cross-listing on an organized exchange, we consider a measure of a country's accounting standards. The accounting standards variable is an index created by examining and rating companies' 1990 annual reports on their omission or inclusion of 90 items. Scores range from a low of 24, (Egypt) to a high of 83 (Sweden). ${ }^{18}$ In addition to the shareholder protection variables, we also attempt to control for other factors that could help to explain cross-listing behavior. We include the log of GNP, and when the equations are estimated on the Worldscope subsample, the log of market value. We also have estimated similar equations using

\footnotetext{
${ }^{17}$ According to La Porta et.al (1998), "The index is formed by adding 1 when (1) the country allows shareholders to mail their proxy vote to the firm, (2) shareholders are not required to deposit their shares prior to the general shareholders' meeting, (3) cumulative voting or proportional representation of minorities in the board of directors is allowed, (4) an oppressed minorities mechanism is in place, (5) the minimum percentage of share capital that entitles a shareholder to call for an extraordinary shareholders' meeting is less than or equal to 10 percent (the sample median), or (6) shareholders have preemptive rights that can be waived only by a shareholders' vote. The index ranges from zero to six".

${ }^{18}$ Ratings are not available for eight countries: Ireland, Kenya, Pakistan, Sri Lanka, Zimbabwe, Ecuador, Indonesia, and Jordan.
} 
other firm-specific variables such as earnings per share and dividends per share, but in no case did the inclusion of any additional variable beyond the log of market value alter the results in a noticeable way.

We use three multivariate specifications to examine the relation between shareholder protection and cross-listings. First, we consider the universe of firms made up of the 1999 Worldscope database of 11,110 non-U.S. firms and estimate the probability that a non-U.S. firm has a cross-listing of any type in the U.S. Second, since cross-listing on an organized exchange has legal implications while OTC crosslistings or 144a listings do not, we estimate the probability that a non-U.S. Worldscope firm has a crosslisting on an organized exchange in the U.S. Finally, we restrict our sample to those firms with some kind of cross-listing and estimate the probability that the cross-listing is on an organized exchange. In this final equation, we also include a dummy variable indicating if the listing was an IPO, since U.S. IPOs occur nonrandomly across countries and are more likely to occur on organized exchanges. We estimate all equations by logit, since the dependent variable in each equation is dichotomous.

Panel A of Table 3 presents results from the first specification, predicting the probability that the firms were cross-listed on any U.S. exchange at that time. In this test (and subsequent ones) we estimate three separate equations, each using a different measure of shareholder protection. ${ }^{19}$ In contrast to the univariate results, Panel A indicates that firms from countries with strong shareholder protection are more likely to cross-list when we use the country's judicial system and the antidirector rights variables as our proxies for shareholder protection. As one would expect, larger firms are more likely to cross-list, and firms from smaller countries (in terms of GNP) are more likely to cross-list, potentially because there are fewer opportunities for these firms to raise capital at home. Panel B of Table 3 presents the results from the second specification, in which the dependent variable takes on a value of one if the firm is listed on an organized exchange only. The results from Panel B are similar to those from Panel A, and suggest that, if anything, when we control for other factors, firms with stronger protection at home are more likely to cross-list in the U.S.

\footnotetext{
19 The measures are highly collinear, which makes the results extremely difficult to interpret when more than one measure is included in an equation.
} 
These multivariate results stand in contrast to the univariate results from Table 2 , in which firms with weak shareholder protection at home are more likely to cross-list. The explanation for this pattern probably lies in the control variables. On average, larger firms are more likely to cross-list, and the French Law firms tend to be larger than the English Law firms. For example, in the Worldscope database, the 2,250 French Civil Law firms have an average market value of \$1.38 billion in 1999, while the 4,488 English Common Law firms have an average market value of only \$924 million. Overall, these results are consistent with the view that managers in weak protection countries are reluctant to cross-list in the U.S. because of the potential loss of private benefits. In other words, the theory suggests that the private benefit effect and the public value effect work in opposite directions; and the multivariate data suggest that the private benefit effect is the larger of the two.

Panel C of Table 3 examines the probability that a firm will cross-list on an organized exchange conditional on its decision to cross-list in the U.S. If the firm is cross-listed on either the New York or Nasdaq exchanges, the dependent variable is given a value of one, and if it is cross-listed Over-theCounter or on Portal, the dependent variable is set to zero. Our first set of equations considers the full set of 1912 firms that choose to cross-list in the U.S., while the second set of regressions is limited to the subset of 960 firms for which we have firm-specific data available through Worldscope. The results appear to be sensitive to the controls for firm size. When we use the entire sample and do not control for size, French Law increases the probability of cross-listing on an organized exchange significantly. However, when we restrict our sample to the Worldscope subsample and control for size, the French Law dummy becomes negative and insignificant. Overall, the relation between shareholder protection at home and cross-listing is unclear, possibly because of the two underlying effects pulling in opposite directions.

\section{Equity Issues and Cross-Listings}

The theoretical arguments discussed above suggest that one reason for cross-listing in the U.S. is to protect minority shareholder interests. Such protections are particularly important when the firm is planning to issue equity in the near future. We expect an increase in equity offerings following all cross- 
listings; however, the increase should be larger when the cross-listing increases shareholder protection.

\subsection{Equity Issues Subsequent to Cross-Listings}

Table 4 documents the volume of equity offerings subsequent to cross-listings. ${ }^{20}$ These data indicate that there is a high incidence of equity offerings subsequent to cross-listings for firms from all countries. For the entire sample of 1912 cross-listings (Panel E), there are a total of 644 firms issuing subsequent equity on 904 separate occasions. These offerings raise a total of $\$ 350$ billion, which is $28 \%$ of the proceeds raised by all non-U.S. offerings during the January 1984 to May 1999 period, clearly an economically important quantity of capital. One-third of the cross-listing firms choose to issue subsequent equity. Of those that do, the average firm issues new shares an average of 1.4 different times.

A metric for gauging whether the quantity of new issues for cross-listed firms is abnormally large is to compare it to the period prior to the cross-listing for same firms. During their two years prior to cross-listing, the entire sample of firms that cross-listed between January 1986 and May 1997 issued 114 equity offerings. In comparison, these same firms issued 167 new equity offerings during the two years subsequent to the cross-listing, an increase of $46 \%$. This calculation does not include offerings coinciding with the cross-listing, and counts simultaneous offerings in different countries as one offering. If we only consider firms listing on an organized U.S. exchange, where the cross-listing provides protection for minority shareholders, the increase is even larger. In the two years prior to the cross-listing, using the same sample as above, there were 44 equity offerings compared to 100 in the two years afterwards. The proceeds from these 100 post-cross-listing equity offerings total $\$ 58.4$ billion, about 4.2 times as high as the proceeds from the 44 offerings in the two years prior to the cross-listing. ${ }^{21}$ There is clearly a substantial increase in equity offerings subsequent to cross-listing on an organized exchange.

\footnotetext{
${ }^{20}$ These data include equity offerings that are floated concurrent with the cross listing, so that all equity issues at and after the cross-listing date are considered to be subsequent issues.

${ }^{21}$ If we include offerings made at the time of the cross-listing, the number of equity offerings made during the two years after cross-listing jumps to 288 with proceeds of $\$ 114$ billion, which is more than six times the number and almost 10 times the proceeds of those in the two years prior. We focus our discussion on the offerings that do not coincide with the cross-listings as a way of biasing our results against the hypothesis that cross-listings are associated with increased equity offerings.
} 
In contrast to the organized-exchange cross-listings, there is no increase in equity offerings for firms listing on the OTC or 144a markets. The number and proceeds of equity offerings for firms listing on OTC and 144a markets is virtually identical in the two years before and after the listing. The OTC firms had 48 offerings for $\$ 10.8$ billion in the two years before the cross-listing, and 47 offerings for $\$ 7.3$ billion in the two years afterwards. The 144a firms had 22 offerings for $\$ 3.7$ billion in the two years before the cross-listing and 20 for $\$ 3.7$ billion in the two years subsequent to the offering. The fact that offering behavior did not change for the OTC and 144a firms suggests that there is no mechanical link between cross-listings and equity offerings.

Comparing all subsequent equity issues across legal systems in Table 4, there is little difference between the primary judicial systems. For firms from French Civil Law countries, 39\% of all listings and $50 \%$ of the listings on an organized exchange issue equity subsequent to the cross-listing. In contrast, from English Common Law countries, $31 \%$ of all listings and $48 \%$ of those listing on an organized exchange issue new equity after cross-listing. Though the firms from French Civil law counties appear somewhat more likely to issue additional equity, these differences are not statistically significant at conventional levels. However, as a fraction of the total equity offerings from these countries, there is a much more substantial difference across legal systems. New issues from the French Civil Law firms which cross-list on an organized exchange total $6.1 \%$ of the total frequency and $32.0 \%$ of the total volume of all new issues from those countries. In contrast, new issues from the English Common Law firms which cross-list on an organized exchange amount to only $3.0 \%$ and $19.6 \%$ of the frequency and volume of all new issues from their countries over the same period. In addition, the average new equity issue from a French Civil Law company is more than three times as large as one from an English Common Law country. These differences are statistically significant at the $1 \%$ level.

Table 5 examines the new issues and proceeds data from Table 4 in a multivariate context. The first six columns of Table 5 estimate (using logit) the probability that a foreign company cross-listing on an organized U.S. exchange will issue new equity at or after the time of its cross-listing, conditional on that firm cross-listing on an organized exchange. The final six columns of Table 5 estimate equations 
predicting the proceeds from a cross-listing firm's subsequent equity issues. We estimate these equations both on the full sample of 765 firms that cross-list on an organized exchange, and on the subset of 377 firms that have firm-specific data available on Worldscope. All these equations use the same three proxies for shareholder protection that we used earlier: judicial origin, antidirector rights, and accounting standards, as well as control variables aimed at controlling for heterogeneity across firms.

The first six columns of Table 5 do not indicate that there is any relation between shareholder protection and the number of subsequent equity issues. Firms from countries with different levels of shareholder protection appear to be equally likely to issue equity after cross-listing. In contrast, the final six columns indicate that there does appear to be a relation between shareholder protection and new equity proceeds. This relation is present with all three proxies for shareholder protection, and is statistically significant using the full sample. However, when we estimate these equations on the Worldscope subsample so that we can control for firm size, the coefficients decrease in absolute value and are no longer statistically significant from zero. The two potential explanations for this finding are that the estimated relation between proceeds and shareholder protection is somehow spurious because of an omitted firm size effect, and that the shareholder protection is more important on the largely smaller firms that are not on Worldscope. To get a rough sense of which of these explanations is more important, we estimate equations similar to those in Table 5 on the Worldscope subsample, without controlling for firm size (i.e., using the econometric specification in columns 7-9). In this specification, we find coefficients on the shareholder protection variables that are somewhat in between those reported in Table 5 for the full sample and Worldscope subsamples, suggesting that both effects are probably important. While it is clear that there is an increase in equity offerings subsequent to a cross-listing, the relation between the value of these offerings and the level of shareholder protection is somewhat less clear.

\subsection{Interpreting the Post-Cross-Listing Equity Offerings}

We have focused our discussion to this point on the hypothesis that firms can increase the value of their equity by bonding themselves to protect their minority shareholders by listing on a U.S. exchange. The overall increase in equity offerings subsequent to cross-listing is consistent with this argument. 
However, there are some equally plausible, and non-mutually exclusive explanations for this finding as well. First, the firms listing in the U.S. could wish to make their stock more easily accessible to U.S. investors. Second, the relation could reflect an increased demand for capital, i.e., firms that have a demand for capital search for equity all over the world and thus attempt to access as many markets as possible. ${ }^{22}$ We next examine the location of the post-cross-listing equity offerings in an effort to provide some insight into the motivation behind a firm's decision to cross-list.

\subsubsection{Cross-listings and non-U.S. Equity Offerings}

To evaluate the explanation that these cross-listings reflect the desire to access U.S. markets, we consider the relation between cross-listings and non-U.S. equity offerings. If the primary reason a firm cross-lists in the United States is to gain access to U.S. investors or U.S. markets, there should be no relation between the level of shareholder protection in a firm's home country and the location of its subsequent equity offerings. Firms from countries with weak shareholder protection should be just as likely to issue subsequent equity inside the United States as firms from countries with strong shareholder protection. However, if one reason for cross-listing is to better protect shareholder rights through registration with the S.E.C., one would expect an increase in equity offerings outside the United States following cross-listings in the U.S. relative to firms that come from countries which already protect the rights of minority shareholders. This effect would occur because firms with weak protection at home will bond themselves to protect shareholders' interests all over the world by cross-listing in the U.S. prior to issuing equity outside the U.S. We test this hypothesis by examining the location of equity offerings subsequent to cross-listings.

\subsubsection{Post-Cross-Listing Equity Offerings and Variation in Shareholder Protection}

We separate equity offerings by location of issuance in Table 6 . In contrast to the overall listing data discussed earlier, these numbers are constructed so that each country a listing is offered in counts as

\footnotetext{
${ }^{22}$ Fanto and Karmel (1997) surveyed 35 foreign companies that had recently listed their securities on the NYSE or Nasdaq. When asked why they chose to cross-list in the U.S., they gave a wide variety of reasons including specific U.S. business reasons, the benefits of U.S. capital markets, some industry-specific reasons, and the desire to expand their U.S. shareholder base.
} 
a separate listing. For example, if on March 1, 1991, a Brazilian firm raises equity simultaneously in the U.S., Brazil and Europe, this is considered to be one U.S. listing, one listing at home, and one elsewhere. These data indicate that firms from French Civil Law countries issue a higher proportion of their subsequent equity offerings outside the United States than do the firms from English Common Law countries. Subsequent to their cross-listing, the organized-exchange-listed French Civil Law firms issue more than 62 percent of their new equity outside the U.S. (29\% in their home market and 34\% elsewhere). In contrast, organized-exchange-listed English Common Law firms place over 65 percent of their subsequent new issues in the U.S. The difference in the proportion of offerings in the U.S. is statistically significant at the $1 \%$ level.

The value of these offerings follows a similar pattern. The French Civil Law firms in our sample issue $\$ 128$ billion of new equity outside the U.S. following their cross-listing ( $\$ 92$ billion at home and $\$ 36$ billion elsewhere). This figure is substantially larger than for the English Common Law firms, which issue only $\$ 47$ billion of new equity outside the U.S. The difference in values is also statistically significant at the $1 \%$ level. In terms of proportions, 81 percent of the new equity raised by these French Civil Law firms comes from outside the U.S., compared to only 63 percent for the English Common Law firms. Firms from German and Scandinavian countries follow a pattern similar to the French Civil Law countries, having proportionately more issues with higher proceeds outside the U.S. These differences suggest that firms from various legal regimes differ substantially in the location of their equity offerings subsequent to cross-listing.

These observations are reinforced by multivariate analysis. Table 7 estimates Logit models predicting whether a particular offering will be done inside or outside the U.S., as well as the fraction of new equity proceeds issued outside the U.S. using a two-tailed Tobit model (left-censored at zero and right-censored at one) fit to a normal distribution. Each type of model is estimated both using our full sample of cross-listed firms and the subsample with firm-specific data available from Worldscope. Both sets of equations use the previously discussed measures of shareholder protection as independent variables. The samples for the equations reported in Table 7 are restricted to those cross-listings on an 
organized U.S. exchange that had at least one subsequent equity offering. The logit equations predicting the location of an offering count each offering in each country as an observation, containing 937 offerings from 372 firms for the full sample. The high ratio of offerings to firms indicates that many of the firms issued new equity more than once and/or in more than one country at a time. The tobit estimating the fraction of proceeds raised outside the U.S. groups all offerings by a single firm into one observation, so that it is estimated on 372 observations for the full sample and 177 for the Worldscope subsample.

The results shown in Table 7 are consistent with the view that shareholder protection is an empirically important reason for cross-listing in the U.S. In all the full sample tests, the coefficients on each of the civil law legal system dummies, as well as the anti-director rights and accounting standards have signs consistent with the shareholder-protection arguments and are significantly different from zero at the $1 \%$ level. When we restrict our sample size and include a control variable for firm size, the results weaken only slightly. These results are consistent with the view that a higher fraction of offerings are placed outside the U.S. when shareholder protections are weaker.

These results suggest that English Common Law firms appear to cross-list in the U.S. for different reasons than do firms from Civil Law countries. English Common Law firms appear to list in the U.S. to gain access to U.S. markets. While Civil Law firms also access U.S. markets, an important motivation appears to be the protections provided by the cross-listing that allow them to issue more equity in their home country and around the world.

\section{Conclusions}

As capital markets have developed internationally, the location of trade has become an increasingly important choice for firms. It is well-recognized that legal protections of shareholder interests can affect valuations and the ability to raise capital externally [see La Porta et. al (1997, 1998, 1999b) and Grinblatt and Titman (1998), p.8]. Cross-listing in the United States affords shareholders of non-U.S. firms a number of legal protections, including the ability to free-ride on shareholder lawsuits of U.S. shareholders for fraudulent statements made anywhere in the world, and requirements that the firm 
follow U.S. GAAP and register with the S.E.C., comply with exchange rules, and follow a number of takeover procedures that have the effect of benefiting small shareholders. Coffee (1999a) and Stulz (1999) have suggested that the ability to cross-list allows a firm to influence the legal regime under which it operates. This explanation for cross-listing complements other explanations that have been discussed in the literature (see Karolyi (1998)). This paper evaluates the argument that one reason why non-U.S. firms choose to cross-list in the United States is the protection of minority shareholder rights associated with S.E.C. registration.

A manager considering cross-listing his firm must consider a number of factors, especially when cross-listing potentially affects his ability to extract private benefits. Such a manager must balance the loss of private benefits with the benefits of increased access to foreign markets and an increase in shareholder protection. Thus the expected empirical relation between cross-listings and incremental shareholder protection is ambiguous. However, there is a clear prediction regarding equity issues, crosslistings, and shareholder protection; equity issues should increase follow cross-listings, and the increase should be larger when the cross-listing is associated with higher shareholder protection. In addition, the increase in equity issues following cross-listings not associated with changes in shareholder protection should primarily occur in the country of the cross-listing, while the increase in equity issues following cross-listings that do increase shareholder protection should occur in all countries.

In this paper, we examine these hypotheses using a database of cross-listing firms and their history of equity issuance. As suggested by the ambiguous theory, the empirical relation between crosslistings and shareholder protection is unclear. Using univariate statistics, it appears as though crosslistings are more common from countries with weak protection; however when we control for other factors such as firm size, the relation reverses itself and cross-listings are more common from countries with strong protection. We document a large increase in both the number and value of equity offerings following cross-listings. Firms from countries with strong shareholder protection are just as likely to issue subsequent equity following their cross-listing as firms from countries with weak shareholder 
protection, and there is some evidence that the firms from the weak-protection countries tend to issue larger quantities.

Probably the cleanest empirical results in the paper concern the location of the equity issues subsequent to a cross-listing. Firms cross-listing from countries with Civil Law tradition (that generally have weak protection at home) place the majority of their subsequent equity issues outside the U.S.; in contrast, firms from English Common Law countries (that tend to have strong protection at home), issue primarily inside the U.S. Multivariate regression analysis supports this evidence, suggesting that following a cross-listing in the U.S., firms from countries with strong shareholder protection are more likely to issue equity in the U.S. while firms with weak shareholder protection are more likely to issue outside the U.S. This empirical finding is consistent with a view that firms with strong protection at home tend to cross-list in order to access U.S. investors and/or markets, while firms from countries with weak shareholder protection will cross-list for the purpose of voluntarily bonding themselves to U.S. securities and market regulations, allowing them to raise capital more easily at home and elsewhere outside the U.S. 


\section{References}

Alexander, G., C. Eun, and S. Janakiramanan (1987) "Asset Pricing and Dual Listing on Foreign Capital Markets: A Note," Journal of Finance, 42, 151-158.

Alexander, G., C. Eun, and S. Janakiramanan (1988) "International Listings and Stock Returns: Some International Evidence," Journal of Financial and Quantitative Analysis, 23, 35-151.

Bacidore, J., and G. Sofianos (2000) "NYSE Specialist Trading in Non-U.S. Stocks", NYSE Working Paper \#2000-05.

Black, F. (1974), International Capital Market Equilibrium with Investment Barriers, Journal of Financial Economics, 1, 337-352.

Cantale, S. (1997), “The Choice of a Foreign Market as a Signal” Unpublished Manuscript, INSEAD.

Coffee, J. (1999a) "The Future as History: The Prospects for Global Convergence in Corporate Governance and its Implications," Northwestern University Law Review, 641-708.

(1999b) "Privatization And Corporate Governance: The Lessons From Securities Market Failure," Journal of Corporation Law, 25, 1-39.

Demirguc-Kunt, A. and V. Maksimovic, (1998) "Law, Finance, and Firm Growth," Journal of Finance, 53, 2107-2138.

Domowitz, I., J. Glen, and A. Madhavan (1998) "International Cross-Listing, and Order-flow Migration: Evidence from Mexico," Journal of Finance, 53, 2001-2028.

Errunza, V. and E. Losq (1985) "International Asset Pricing under Mild Segmentation: Theory and Test," Journal of Finance, 40, 105-124.

and D. Miller (1999) "Market Segmentation and the Cost of Capital in International Equity Markets,” Working Paper. Texas A\&M University.

Eun C. and S. Janakiramanan (1986) "A Model of International Asset Pricing with a Constraint on the Foreign Equity Ownership,” Journal of Finance, 41, 897-914.

Eun, C. and B. Resnick (1997) International Financial Management, Irwin McGraw-Hill: Boston.

Fanto, J. and R. Karmel (1997) "A Report on the Attitudes of Foreign Companies Regarding a U.S. Listing," Stanford Journal of Law, Business \& Finance, 3:1, 51-75.

Foerster, S.R. and A. Karolyi (1993) "International Listings of Stocks: The Case of Canada and the U.S.," Journal of International Business Studies, 24, 763-784.

Foerster, S.R. and A. Karolyi (1998) "Multimarket Trading and Liquidity: A Transactions Data Analysis of Canada-U.S. Interlistings," Journal of International Financial Markets, Institutions and Money, 8, 393412. 
Foerster, S.R. and A. Karolyi (1999) "The Effects of Market Segmentation and Investor Recognition on Asset Prices: Evidence from Foreign Stocks Listing in the United States," Journal of Finance, 54, 9811013.

Fuerst, O. (1998), A Theoretical Analysis of the Investor Protection Regulations Argument for Global Listing of Stocks," Working Paper. Yale School of Management.

Grinblatt, M. and S. Titman (1998) Financial Markets and Corporate Strategy, Irwin McGraw-Hill: Boston, MA.

Huddart, S., J. Hughes, and M. Brunnermeier (1999) "Disclosure Requirements and Stock Exchange Listing Choice in an International Context," Journal of Accounting and Economics, 26, 237-269.

Jayaraman, N., K. Shastri, and K. Tandon (1993) "The Impact of International Cross-Listings on Risk and Return: Evidence from American Depositary Receipts," Journal of Banking and Finance, 17, 91-103.

Karolyi, G. A. (1998) Why Do Companies List Their Shares Abroad? (A Survey of the Evidence and its Managerial Implications), Volume 7, Number 1, Salomon Brothers Monograph Series, New York University, January 1998.

La Porta, R., F. Lopez-de-Silanes, A. Shleifer, and R. Vishny (1997) "Legal Determinants of External Finance", Journal of Finance, 52, 1131-50.

Political Economy, 106, 1113-1155. (1998) "Law and Finance," Journal of

Governance," Journal of Financial Economics, forthcoming.

(1999a) "Investor Protection and Corporate

Valuation,” Working Paper, Harvard University.

(1999b) "Investor Protection and Corporate

Policies around the World," Journal of Finance, forthcoming.

(2000) “Agency Problems and Dividend

Licht, Amir (2000) "Regulatory Arbitrage for Real: International Securities Regulation in a World of Interacting Securities Markets,” Virginia Journal of International Law, 38, 563-636.

Lins, K., D. Strickland, and M. Zenner (1999), "Do non-U.S. firms issue stock on U.S. equity markets to relax capital constraints?" Working Paper, University of North Carolina at Chapel Hill.

Lombardo, D. and M. Pagano (2000) "Law and Equity Markets: A Simple Model," Working Paper, CSEF and University of Salerno.

Merton, R. (1987) "A Simple Model of Capital Market Equilibrium with Incomplete Information," Journal of Finance, 42, 483-510.

Miller, D. (1999), "The market reaction to international cross-listings: Evidence from Depositary Receipts,” Journal of Financial Economics, 51, 103-123. 
Moel, A. (1999) "The role of information disclosure on stock market listing decisions: The case of foreign firms listing in the US," Working Paper, Harvard Business School.

Pagano, M., A. Roell, and J. Zechner (1999) “The Geography of Equity Listing: Why do European Companies List Abroad?" Working paper, Princeton University.

Pagano, M. and P. Volpin (2000) “The Political Economy of Corporate Governance," Working Paper, CSEF and University of Salerno.

Rajan, R. and L. Zingales, (1999) “The Politics of Financial Development," Working Paper, University of Chicago.

Saudagaran, S. and G. Biddle (1995) "Foreign Listing Location: A Study of MNCs and Stock Exchanges In Eight Countries," Journal of International Business Studies, $2^{\text {nd }}$ Qtr., 319-341.

Shleifer, A. and R. Vishny (1986) "Large Shareholders and Corporate Control," Journal of Political Economy, 94, 461-488.

Smith, K. and G. Sofianos (1997) "The Impact of a NYSE listing on the Global Trading of non-U.S. Stocks," Working paper 97-02, New York Stock Exchange.

Stapleton, R. and M. Subrahmanyam (1977) "Market Imperfections, Capital Market Equilibrium, and Corporate Finance, Journal of Finance, 32, 307-319.

Stulz, R. (1981) "On the Effects of Barriers to International Investment," Journal of Finance, 36, 923934.

(1999) "Globalization of Equity Markets and the Cost of Capital," Journal of Applied Corporate Finance, 12, 8-25.

Switzer, L., (1986) "The Benefits and Costs of Listing Canadian Stocks in U.S. Markets", in L. Sarna (ed.) Corporate Structure, Finance and Operations, Carswell Co. Toronto, 241-254.

Tinic, S. and R. West (1974) "Marketability of Common Stocks in Canada and the U.S.A.: A Comparison of Agent Versus Dealer Dominated Markets,” Journal of Finance, 29, 729-746. 


\section{Table 1}

\section{Panel A \\ Federal Reporting Requirements}

\begin{tabular}{|c|c|c|c|}
\hline $\begin{array}{c}\text { NYSE or Nasdaq } \\
\text { Non-Capital } \\
\text { Raising }\end{array}$ & $\begin{array}{c}\text { NYSE or Nasdaq } \\
\text { Capital Raising }\end{array}$ & OTC & $144 a$ \\
\hline Form 20-F & Form 20-F & Exempt from filing & Exempt from filing \\
\hline Filed annually & Filed annually & $\begin{array}{l}\text { Form } 20-\mathrm{F} \text { under } \\
\text { Rule } 12 \mathrm{~g} 3-2(\mathrm{~b})\end{array}$ & $\begin{array}{l}\text { Form } 20-F \text { under } \\
\text { Rule } 144\end{array}$ \\
\hline $\begin{array}{l}\text { Financial } \\
\text { Statements must be } \\
\text { partially reconciled } \\
\text { to GAAP }\end{array}$ & $\begin{array}{l}\text { Financial } \\
\text { Statements must be } \\
\text { fully reconciled to } \\
\text { GAAP }\end{array}$ & $\begin{array}{l}\text { No GAAP } \\
\text { reconciliation } \\
\text { required }\end{array}$ & $\begin{array}{l}\text { No GAAP } \\
\text { reconciliation } \\
\text { required }\end{array}$ \\
\hline SEC Registration & SEC Registration & No SEC & No SEC \\
\hline $\begin{array}{l}\text { Statement Form F- } 6 \\
\text { must be filed }\end{array}$ & $\begin{array}{l}\text { Forms F-1 and F- } 6 \\
\text { must be filed }\end{array}$ & $\begin{array}{l}\text { Registration } \\
\text { required }\end{array}$ & $\begin{array}{l}\text { Registration } \\
\text { required }\end{array}$ \\
\hline
\end{tabular}

\section{Panel B \\ Quantitative Standards}

\begin{tabular}{lllll}
\hline & \multicolumn{2}{c}{ NYSE* } & Nasdaq & OTC \& 144a \\
\hline & U.S. Standards & $\begin{array}{l}\text { Non-U.S. } \\
\text { Standards }\end{array}$ & & \\
\hline $\begin{array}{l}\text { Round-lot } \\
\text { Holders }\end{array}$ & 2,000 & 5,000 & 300 & N/A \\
\hline Public Shares & 1 million & 2.5 million & 1 million & N/A \\
\hline $\begin{array}{l}\text { Market Value of } \\
\text { Public Shares }\end{array}$ & $\begin{array}{l}\text { \$100 million } \\
(\$ 60 \text { million for IPOs })\end{array}$ & $\$ 100$ million & $\begin{array}{l}\text { \$50 } \\
\text { million }\end{array}$ & N/A \\
\hline Earnings & \$2.5 million & \$25 million & $\$ 750,000$ & N/A \\
\hline $\begin{array}{l}\text { Net Tangible } \\
\text { Assets }\end{array}$ & N/A & N/A & $\$ 2$ million & N/A \\
\hline $\begin{array}{l}\text { Operating Cash } \\
\text { Flow }\end{array}$ & $\begin{array}{l}\text { \$25 million } \\
\text { (over 3 yrs })\end{array}$ & $\$ 25$ million & N/A & N/A \\
\hline
\end{tabular}

* To list on the NYSE, firms can choose to meet either the U.S. standards or the non-U.S. standards. Only shares and assets in the U. S. can be used to meet the U.S. standards. The non-U.S. standards can be met with shares and assets worldwide. A firm must meet either all the U.S. standards or all the non-U.S. standards. 


\section{Panel C \\ Corporate Governance Standards}

\section{Nasdaq}

- Distribute annual reports to shareholders

- Appoint a minimum of two independent directors

- Establish and maintain an audit committee, with the majority of the members consisting of outside directors

- Hold an annual meeting of shareholders

- Establish a quorum of not less than $1 / 3$ of the outstanding shares

- Provide proxy statements to shareholders

- Require shareholder approval for the issuance of new securities

- Submit to an audit by an independent public accountant

\section{NYSE}

No formal standards except to receive a written opinion from a home country counsel that the firm's corporate governance standards are in-line with all home country laws

\section{OTC \& 144a}

None

\section{Panel D \\ Financial Requirements}

\begin{tabular}{cclc}
\hline \multicolumn{1}{c}{ NYSE } & \multicolumn{1}{c}{ Nasdaq } & OTC \& 144a \\
\hline Original Fee & $\$ 36,800$ & $\begin{array}{l}\text { Total Shares } \\
\text { Outstanding }\end{array}$ & None \\
& & $<1$ million & $\$ 29,525$ \\
\hline plus & Per Million & 1 to 2 million & 33,750 \\
\hline Shares or ADRs & $\$ 14,750$ & 2 to 3 million & 43,750 \\
\hline $1^{\text {st }}$ and $2^{\text {nd }}$ million & 14,750 & 3 to 4 million & 48,750 \\
\hline $3^{\text {rd }}$ and $4^{\text {th }}$ million & 7,400 & 4 to 5 million & 55,000 \\
\hline $5^{\text {th }}$ and up to 300 million & 1,900 & 5 to 6 million & 58,725 \\
\hline In excess of 300 million & 100,000 & 6 to 7 million & 61,875 \\
\hline Minimum Fee & 7 to 8 million & 64,375 \\
\hline & 8 to 9 million & 67,875 \\
\hline & 9 to 10 million & 70,625 \\
\hline & 10 to 11 million & 73,875 \\
\hline & 11 to 12 million & 76,625 \\
\hline & 12 to 13 million & 79,875 \\
\hline & 13 to 14 million & 82,000 \\
\hline & 14 to 15 million & 83,500 \\
\hline & 15 to 16 million & 85,000 \\
\hline & $>16$ million & 90,000 \\
\hline
\end{tabular}




\section{Table 2 \\ Cross-Listings by Exchange and per 100 Domestic Listed Firms}

In this table, each panel looks at one of the four major legal systems. The table shows the number of firms that were cross-listed in the United States (both depositary receipts and direct cross-listings) for each country with that particular legal system as of June 1999. Columns one through four sort the firms by the exchange that they are listed on. Column five is the total of columns one through four. Column six gives the total number of domestic listed firms from each country. Column seven calculates the total number of cross-listed firms from each country per 100 domestic listed firm. Column eight calculates only the number of cross-listed firms that are listed on an "organized exchange" per 100 domestic listed firms. The NYSE and Nasdaq exchanges are considered to be the organized exchanges and are significant since these are the exchanges that require specific accounting and disclosure information in order for a firm to cross-list on it.

\section{Panel A \\ English Common Law Countries}

\begin{tabular}{|c|c|c|c|c|c|c|c|c|}
\hline \multirow[t]{2}{*}{ Country } & \multicolumn{5}{|c|}{ Cross-Listings } & \multirow{2}{*}{$\begin{array}{l}\text { Domestic } \\
\text { Firms }\end{array}$} & \multirow{2}{*}{$\begin{array}{l}\text { CLs per } \\
100 \text { firms }\end{array}$} & \multirow{2}{*}{$\begin{array}{l}\text { Org Exch CLs } \\
\text { per } 100 \text { firms }\end{array}$} \\
\hline & NYSE & Nasdaq & OTC & $144 a$ & Total & & & \\
\hline Australia & 13 & 18 & 74 & 5 & 110 & 1207 & 9.11 & 2.57 \\
\hline Canada & 69 & 124 & 285 & 0 & 478 & 1250 & 38.24 & 15.44 \\
\hline Hong Kong & 9 & 14 & 98 & 0 & 121 & 608 & 19.90 & 3.78 \\
\hline India & 0 & 1 & 0 & 48 & 49 & 7686 & 0.64 & 0.01 \\
\hline Ireland & 4 & 11 & 6 & 0 & 21 & 74 & 28.38 & 20.27 \\
\hline Israel & 5 & 67 & 10 & 0 & 82 & 778 & 10.54 & 9.25 \\
\hline Kenya & 0 & 0 & 0 & 0 & 0 & 65 & 0.00 & 0.00 \\
\hline Malaysia & 0 & 0 & 10 & 0 & 10 & 571 & 1.75 & 0.00 \\
\hline New Zealand & 5 & 2 & 1 & 0 & 8 & 262 & 3.05 & 2.67 \\
\hline Nigeria & 0 & 0 & 0 & 1 & 1 & 191 & 0.52 & 0.00 \\
\hline Pakistan & 0 & 0 & 0 & 3 & 3 & 861 & 0.35 & 0.00 \\
\hline Singapore & 4 & 3 & 17 & 1 & 25 & 320 & 7.81 & 2.19 \\
\hline South Africa & 3 & 6 & 32 & 11 & 52 & 682 & 7.62 & 1.32 \\
\hline Sri Lanka & 0 & 0 & 0 & 1 & 1 & 227 & 0.44 & 0.00 \\
\hline Thailand & 0 & 0 & 13 & 2 & 15 & 414 & 3.62 & 0.00 \\
\hline United Kingdom & 56 & 45 & 90 & 13 & 204 & 2119 & 9.63 & 4.77 \\
\hline Zimbabwe & 0 & 0 & 0 & 0 & 0 & 65 & 0.00 & 0.00 \\
\hline Totals & 168 & 291 & 636 & 85 & 1180 & 17381 & & \\
\hline Per 100 firms & 0.96 & 1.67 & 3.66 & 0.49 & 6.79 & & & 2.64 \\
\hline
\end{tabular}




\section{Panel B \\ French Civil Law Countries}

\begin{tabular}{|c|c|c|c|c|c|c|c|c|}
\hline \multirow[t]{2}{*}{ Country } & \multicolumn{5}{|c|}{ Cross-Listings } & \multirow{2}{*}{$\begin{array}{l}\text { Domestic } \\
\text { Firms }\end{array}$} & \multirow{2}{*}{$\begin{array}{l}\text { CLs per } \\
100 \text { firms }\end{array}$} & \multirow{2}{*}{$\begin{array}{l}\text { Org Exch CLs } \\
\text { per } 100 \text { firms }\end{array}$} \\
\hline & NYSE & Nasdaq & OTC & $144 a$ & Total & & & \\
\hline Argentina & 10 & 2 & 5 & 7 & 24 & 168 & 14.29 & 7.14 \\
\hline Belgium & 1 & 3 & 1 & 0 & 5 & 158 & 3.16 & 2.53 \\
\hline Brazil & 24 & 1 & 35 & 11 & 71 & 584 & 12.16 & 4.28 \\
\hline Chile & 24 & 1 & 1 & 2 & 28 & 299 & 9.36 & 8.36 \\
\hline Colombia & 3 & 0 & 3 & 5 & 11 & 121 & 9.09 & 2.48 \\
\hline Ecuador & 0 & 0 & 2 & 1 & 3 & 163 & 1.84 & 0.00 \\
\hline Egypt & 0 & 0 & 1 & 5 & 6 & 232 & 2.59 & 0.00 \\
\hline France & 15 & 9 & 15 & 7 & 46 & 476 & 9.66 & 5.04 \\
\hline Greece & 1 & 4 & 3 & 5 & 13 & 227 & 5.73 & 2.20 \\
\hline Indonesia & 4 & 1 & 2 & 2 & 9 & 244 & 3.69 & 2.05 \\
\hline Italy & 15 & 6 & 0 & 12 & 33 & 226 & 14.60 & 9.29 \\
\hline Jordan & 0 & 0 & 0 & 1 & 1 & 112 & 0.89 & 0.00 \\
\hline Mexico & 30 & 5 & 33 & 18 & 86 & 227 & 37.89 & 15.42 \\
\hline Netherlands & 19 & 21 & 13 & 3 & 56 & 334 & 16.77 & 11.98 \\
\hline Peru & 4 & 0 & 4 & 2 & 10 & 252 & 4.37 & 1.59 \\
\hline Philippines & 3 & 0 & 7 & 9 & 19 & 216 & 8.80 & 1.39 \\
\hline Portugal & 4 & 0 & 2 & 3 & 9 & 195 & 4.62 & 2.05 \\
\hline Spain & 15 & 0 & 5 & 5 & 25 & 383 & 6.53 & 3.92 \\
\hline Turkey & 0 & 0 & 5 & 11 & 16 & 193 & 8.29 & 0.00 \\
\hline Uruguay & 0 & 0 & 0 & 0 & 0 & 24 & 0.00 & 0.00 \\
\hline Venezuela & 3 & 0 & 13 & 4 & 20 & 101 & 19.80 & 2.97 \\
\hline Totals & 175 & 53 & 150 & 113 & 491 & 4935 & & \\
\hline Per 100 firms & 3.55 & 1.07 & 3.04 & 2.29 & 9.95 & & & 4.62 \\
\hline
\end{tabular}




\section{Panel C \\ German Civil Law Countries}

\begin{tabular}{|c|c|c|c|c|c|c|c|c|}
\hline \multirow[t]{2}{*}{ Country } & \multicolumn{5}{|c|}{ Cross-Listings } & \multirow{2}{*}{$\begin{array}{l}\text { Domestic } \\
\text { Firms }\end{array}$} & \multirow{2}{*}{$\begin{array}{l}\text { CLs per } \\
100 \text { firms }\end{array}$} & \multirow{2}{*}{$\begin{array}{l}\text { Org Exch CLs } \\
\text { per } 100 \text { firms }\end{array}$} \\
\hline & NYSE & Nasdaq & OTC & $144 a$ & Total & & & \\
\hline Austria & 0 & 0 & 15 & 4 & 19 & 112 & 16.96 & 0.00 \\
\hline Germany & 8 & 5 & 18 & 5 & 36 & 421 & 8.55 & 3.09 \\
\hline Japan & 12 & 10 & 21 & 4 & 47 & 2253 & 2.09 & 0.98 \\
\hline South Korea & 3 & 0 & 0 & 19 & 22 & 745 & 2.95 & 0.40 \\
\hline Switzerland & 4 & 2 & 12 & 4 & 22 & 240 & 9.17 & 2.50 \\
\hline Taiwan & 1 & 2 & 0 & 26 & 29 & 313 & 9.27 & 0.96 \\
\hline Totals & 28 & 19 & 66 & 62 & 175 & 4084 & & \\
\hline Per 100 firms & 0.69 & 0.47 & 1.64 & 1.52 & 4.29 & & & 1.15 \\
\hline
\end{tabular}

\section{Panel D \\ Scandinavian Civil Law Countries}

\begin{tabular}{|c|c|c|c|c|c|c|c|c|}
\hline \multirow[t]{2}{*}{ Country } & \multicolumn{5}{|c|}{ Cross-Listings } & \multirow{2}{*}{$\begin{array}{l}\text { Domestic } \\
\text { Firms }\end{array}$} & \multirow{2}{*}{$\begin{array}{l}\text { CLs per } \\
100 \text { firms }\end{array}$} & \multirow{2}{*}{$\begin{array}{l}\text { Org Exch CLs } \\
\text { per } 100 \text { firms }\end{array}$} \\
\hline & NYSE & Nasdaq & OTC & $\overline{144 a}$ & Total & & & \\
\hline Denmark & 2 & 2 & 0 & 2 & 6 & 74 & 8.11 & 5.41 \\
\hline Finland & 3 & 1 & 3 & 4 & 11 & 73 & 15.07 & 5.48 \\
\hline Norway & 6 & 1 & 9 & 5 & 21 & 63 & 33.33 & 11.11 \\
\hline Sweden & 3 & 13 & 9 & 3 & 28 & 125 & 22.40 & 12.80 \\
\hline Totals & 14 & 17 & 21 & 14 & 66 & 335 & & \\
\hline Per 100 firms & 4.18 & 5.07 & 6.27 & 4.18 & 19.70 & & & 9.25 \\
\hline
\end{tabular}




\section{Table 3 \\ Multivariate Estimates of the Probability of Cross-Listing}

Each panel looks at the probability of a foreign firm cross-listing its equity on a U.S. exchange. Panel A uses a sample of 11,110 foreign firms that were listed in the Worldscope database in 1999, and examines the unconditional probability that they were cross-listed on some (any) U.S. exchange at that time. Panel B uses the same sample of firms to examine the unconditional probability that they were cross-listed on an organized exchange (NYSE or Nasdaq). Panel C considers the probability that a foreign firm would chose to list itself on an organized exchange conditional on its decision to cross-list in the U.S. Panel C uses two separate samples of firms; all firms that cross-listed, and a subsample of those firms for which we were able to obtain firm-specific data from Worldscope. Each panel displays the results of three separate multivariate Logit regressions; each of which uses a different measure of shareholder protection. The legal tradition explanatory variables (French, German and Scandinavian) are dummy variables taking a value of one if the firm came from a country with that legal tradition and zero otherwise. Since these are the civil law legal traditions, they each measure their difference from firms that come from countries with an English Common Law tradition. The second and third explanatory variables are taken from La Porta et. al $(1997,1998)$. The Antidirector Rights variable is an index aggregating six significant shareholder rights. The Accounting Standards variable is an index created by examining and rating companies' 1990 annual reports on their inclusion or omission of 90 items. For these two variables, a higher value means (respectively), greater rights for minority shareholders and tighter accounting standards. These variables are country-specific and are applied to each firm based on its home country. In panel C, the IPO dummy is given a value of one if the cross-listing occurs simultaneously with the firm's IPO and zero if the firm already had publicly traded shares. The log of GNP variable is used in each regression to control for the size of the firm's home country. For those samples which use firms for which we have Worldscope data available, we include a variable for the log of the firm's market value to control for the size of the firm. $p$-values appear in parentheses below each coefficient estimate.

\section{Panel A Unconditional Probability of Cross-listing}

\begin{tabular}{|c|c|c|c|}
\hline \multirow[t]{2}{*}{ Explanatory Variable(s) } & \multicolumn{3}{|c|}{$\mathrm{N}=11,110$} \\
\hline & $\# 1$ & $\# 2$ & $\# 3$ \\
\hline French Law Dummy & $\begin{array}{l}-0.3140 \\
(.0007)\end{array}$ & & \\
\hline German Law Dummy & $\begin{array}{c}-1.0341 \\
(.0001)\end{array}$ & & \\
\hline Scandinavian Law Dummy & $\begin{array}{l}-0.8436 \\
(.0001)\end{array}$ & & \\
\hline Antidirector Rights & & $\begin{array}{l}0.1768 \\
(.0001)\end{array}$ & \\
\hline Accounting Standards & & & $\begin{array}{l}-0.0074 \\
(.0834)\end{array}$ \\
\hline Log of Market Value & $\begin{array}{l}0.6887 \\
(.0001)\end{array}$ & $\begin{array}{l}0.6881 \\
(.0001)\end{array}$ & $\begin{array}{l}0.6683 \\
(.0001)\end{array}$ \\
\hline Log of GNP & $\begin{array}{l}-0.3693 \\
(.0001)\end{array}$ & $\begin{array}{l}-0.4836 \\
(.0001)\end{array}$ & $\begin{array}{l}-0.4891 \\
(.0001)\end{array}$ \\
\hline Log-Likelihood & -3113 & -3113 & -3052 \\
\hline
\end{tabular}




\section{Panel B \\ Unconditional Probability of Cross-listing on an Organized Exchange}

\begin{tabular}{l|ccc}
\hline Explanatory Variable(s) & \multicolumn{3}{|c}{$\mathbf{N = 1 1 , 1 1 0}$} \\
\hline French Law Dummy & -0.1781 & & \\
& $(.1788)$ & & \\
German Law Dummy & -1.8000 & & \\
& $(.0001)$ & & \\
Scandinavian Law Dummy & -0.3590 & & \\
& $(.1409)$ & & \\
Antidirector Rights & & 0.2142 & \\
& & $(.0001)$ & \\
Accounting Standards & & & 0.0125 \\
& & & \\
& & & \\
Log of Market Value & 0.7664 & 0.7790 & 0.7503 \\
& $(.0001)$ & $(.0001)$ & $(.0001)$ \\
Log of GNP & 0.0935 & -0.3302 & -0.3301 \\
& $(.0001)$ & $(.0001)$ & $(.0001)$ \\
Log-Likelihood & -1590 & -1590 & -1556 \\
\hline
\end{tabular}

\section{Panel C}

Probability of Cross-listing on an Organized Exchange Conditional on the Decision to Cross-list

\begin{tabular}{|c|c|c|c|c|c|c|}
\hline \multirow[t]{2}{*}{ Explanatory Variable(s) } & \multicolumn{3}{|c|}{$\begin{array}{c}\text { Full Sample } \\
\quad \mathrm{N}=1912\end{array}$} & \multicolumn{3}{|c|}{$\begin{array}{l}\text { Worldscope Subsample } \\
\qquad \mathrm{N}=960\end{array}$} \\
\hline & $\# 1$ & $\# 2$ & \#3 & $\# 1$ & $\# 2$ & $\# 3$ \\
\hline French Law Dummy & $\begin{array}{l}0.2816 \\
(.0247)\end{array}$ & & & $\begin{array}{l}-0.0487 \\
(.7981)\end{array}$ & & \\
\hline German Law Dummy & $\begin{array}{l}-0.7746 \\
(0002)\end{array}$ & & & $\begin{array}{l}-1.4234 \\
(.0001)\end{array}$ & & \\
\hline Scandinavian Law Dummy & $\begin{array}{l}0.6882 \\
(.0138)\end{array}$ & & & $\begin{array}{l}0.3230 \\
(.3531)\end{array}$ & & \\
\hline Antidirector Rights & & $\begin{array}{l}0.0518 \\
(.1941)\end{array}$ & & & $\begin{array}{l}0.1961 \\
(.0009)\end{array}$ & \\
\hline Accounting Standards & & & $\begin{array}{r}0.0080 \\
(.1920)\end{array}$ & & & $\begin{array}{l}0.0256 \\
(.0048)\end{array}$ \\
\hline IPO Dummy & $\begin{array}{l}3.7759 \\
(.0001)\end{array}$ & $\begin{array}{l}3.7773 \\
(.0001)\end{array}$ & $\begin{array}{l}3.7123 \\
(.0001)\end{array}$ & $\begin{array}{l}1.6983 \\
(.0001)\end{array}$ & $\begin{array}{l}1.7163 \\
(.0001)\end{array}$ & $\begin{array}{l}1.7116 \\
(.0001)\end{array}$ \\
\hline Log of Market Value & & & & $\begin{array}{l}0.2897 \\
(.0001)\end{array}$ & $\begin{array}{l}0.2836 \\
(.0001)\end{array}$ & $\begin{array}{l}0.2367 \\
(.0001)\end{array}$ \\
\hline Log of GNP & $\begin{array}{l}0.3145 \\
(.0001)\end{array}$ & $\begin{array}{l}0.2043 \\
(.0001)\end{array}$ & $\begin{array}{l}0.2057 \\
(.0002)\end{array}$ & $\begin{array}{l}0.3994 \\
(.0001)\end{array}$ & $\begin{array}{l}0.2279 \\
(.0010)\end{array}$ & $\begin{array}{l}0.2292 \\
(.0017)\end{array}$ \\
\hline Log-Likelihood & -1286 & -1286 & -1258 & -607 & -607 & -597 \\
\hline
\end{tabular}




\section{Table 4 \\ New Issues and Proceeds from Cross-Listed Firms}

In this table, each panel looks at one of the four major legal systems. The first row of each panel gives the number of firms from that legal system that were cross-listed in the U.S. in June, 1999. The second row states how many of those firms issued new equity at the same time as or after their cross-listing date, and what percentage of the firms cross-listing on that exchange issued the equity. The third row tells us how many times new equity was issued from those firms and the average number of new equity issues conditional on issuing equity. If a firm issued equity in more than one market at the same time, it is counted as a single issue in this table. The fourth row reports the total proceeds from these equity issues in millions of U.S. dollars and the average proceeds per issue. The first four columns break down the data by the exchange that the foreign firm's shares cross-listed on. Column five is the total of columns one through four. Column six is the total of the NYSE and Nasdaq columns. This is significant since these are the exchanges that require specific accounting and disclosure information in order for a firm to crosslist on it. The final column states the new issues and proceeds on an organized exchange (NYSE or Nasdaq) as a percentage of the total new issues and proceeds issued between 1/1/84 and 5/1/99 from firms domiciled in the countries with that legal system.

Panel A

English Common Law Countries

\begin{tabular}{|l|c|c|c|c|c|c|c|}
\hline & NYSE & Nasdaq & OTC & 144a & Total & Org. Exch & $\begin{array}{l}\text { Percent of all } \\
\text { New Issues }\end{array}$ \\
\hline $\begin{array}{l}\text { Number of Cross-listings } \\
(\% \text { of total) }\end{array}$ & $\begin{array}{c}168 \\
(14 \%)\end{array}$ & $\begin{array}{c}291 \\
(25 \%)\end{array}$ & $\begin{array}{c}636 \\
(54 \%)\end{array}$ & $\begin{array}{c}85 \\
(7 \%)\end{array}$ & $\begin{array}{c}1180 \\
(100 \%)\end{array}$ & $\begin{array}{c}459 \\
(36 \%)\end{array}$ & \\
\hline $\begin{array}{l}\text { CLs issuing equity after listing } \\
\text { (\% of cross-listings) }\end{array}$ & $\begin{array}{c}67 \\
(40 \%)\end{array}$ & $\begin{array}{c}154 \\
(53 \%)\end{array}$ & $\begin{array}{c}99 \\
(16 \%)\end{array}$ & $\begin{array}{c}41 \\
(48 \%)\end{array}$ & $\begin{array}{c}361 \\
(31 \%)\end{array}$ & $\begin{array}{c}221 \\
(48 \%)\end{array}$ & \\
\hline New Issues after listing & 99 & 213 & 119 & 48 & 479 & 312 & $3.0 \%$ \\
(Issues per issuing cross-listing) & $(1.5)$ & $(1.4)$ & $(1.2)$ & $(1.2)$ & $(1.3)$ & $(1.4)$ & $19 \%$ \\
\hline $\begin{array}{l}\text { Proceeds after listing (\$ mill.) } \\
\text { (Ave. proceeds per new issue) }\end{array}$ & 57,370 & $\begin{array}{c}17,605 \\
(579)\end{array}$ & $\begin{array}{c}13,681 \\
(115)\end{array}$ & $\begin{array}{c}11,894 \\
(248)\end{array}$ & $\begin{array}{c}100,550 \\
(210)\end{array}$ & $\begin{array}{c}74,975 \\
(240)\end{array}$ & $19.6 \%$ \\
\hline
\end{tabular}

All Firms in English Common Law Countries 1/1/84 - 5/1/99

Total Number of New Issues - 10,315

Total Proceeds from New Issues - \$382,496 mill.

\section{Panel B}

French Civil Law Countries

\begin{tabular}{|l|c|c|c|c|c|c|c|}
\hline & NYSE & Nasdaq & OTC & $\mathbf{1 4 4 a}$ & Total & Org. Exch & $\begin{array}{l}\text { Percent of all } \\
\text { New Issues }\end{array}$ \\
\hline $\begin{array}{l}\text { Number of Cross-listings } \\
(\% \text { of total) }\end{array}$ & $\begin{array}{c}175 \\
(36 \%)\end{array}$ & $\begin{array}{c}53 \\
(11 \%)\end{array}$ & $\begin{array}{c}150 \\
(31 \%)\end{array}$ & $\begin{array}{c}113 \\
(23 \%)\end{array}$ & $\begin{array}{c}491 \\
(100 \%)\end{array}$ & $\begin{array}{c}228 \\
(46 \%)\end{array}$ & \\
\hline $\begin{array}{l}\text { CLs issuing equity after listing } \\
(\% \text { of cross-listings) }\end{array}$ & $\begin{array}{c}82 \\
(47 \%)\end{array}$ & $\begin{array}{c}33 \\
(62 \%)\end{array}$ & $\begin{array}{c}20 \\
(13 \%)\end{array}$ & $\begin{array}{c}57 \\
(50 \%)\end{array}$ & $\begin{array}{c}192 \\
(39 \%)\end{array}$ & $\begin{array}{c}115 \\
(50 \%)\end{array}$ & \\
\hline New Issues after listing & 145 & 49 & 27 & 72 & 293 & 194 & $6.1 \%$ \\
(Issues per issuing cross-listing) & $(1.8)$ & $(1.5)$ & $(1.4)$ & $(1.3)$ & $(1.3)$ & $(1.7)$ & $32.0 \%$ \\
\hline $\begin{array}{l}\text { Proceeds after listing (\$mill.) } \\
\text { (Ave. proceeds per new issue) }\end{array}$ & $\begin{array}{c}151,009 \\
(1041)\end{array}$ & $\begin{array}{c}7,334 \\
(150)\end{array}$ & $\begin{array}{c}6,977 \\
(258)\end{array}$ & $\begin{array}{c}21,524 \\
(299)\end{array}$ & $\begin{array}{c}186,843 \\
(638)\end{array}$ & $\begin{array}{c}158,343 \\
(816)\end{array}$ & \\
\hline
\end{tabular}

All Firms in French Civil Law Countries 1/1/84 - 5/1/99

Total Number of New Issues - 3190

Total Proceeds from New Issues - \$494,460 mill. 


\section{Panel C}

\section{German Civil Law Countries}

\begin{tabular}{|c|c|c|c|c|c|c|c|}
\hline & NYSE & Nasdaq & OTC & $144 a$ & Total & Org. Exch & $\begin{array}{l}\text { Percent of all } \\
\text { New Issues }\end{array}$ \\
\hline $\begin{array}{l}\text { Number of Cross-listings } \\
\text { (\% of total) }\end{array}$ & $\begin{array}{c}28 \\
(16 \%)\end{array}$ & $\begin{array}{c}19 \\
(11 \%)\end{array}$ & $\begin{array}{c}66 \\
(38 \%) \\
\end{array}$ & $\begin{array}{c}62 \\
(35 \%) \\
\end{array}$ & $\begin{array}{c}175 \\
(100 \%) \\
\end{array}$ & $\begin{array}{c}47 \\
(27 \%) \\
\end{array}$ & \\
\hline $\begin{array}{l}\text { CLs issuing equity after listing } \\
\text { (\% of cross-listings) }\end{array}$ & $\begin{array}{c}14 \\
(50 \%) \\
\end{array}$ & $\begin{array}{c}9 \\
(47 \%) \\
\end{array}$ & $\begin{array}{c}12 \\
(18 \%) \\
\end{array}$ & $\begin{array}{c}28 \\
(45 \%) \\
\end{array}$ & $\begin{array}{c}63 \\
(36 \%) \\
\end{array}$ & $\begin{array}{c}23 \\
(49 \%) \\
\end{array}$ & \\
\hline $\begin{array}{l}\text { New Issues after listing } \\
\text { (Issues per issuing cross-listing) }\end{array}$ & $\begin{array}{c}25 \\
(1.8) \\
\end{array}$ & $\begin{array}{c}10 \\
(1.1)\end{array}$ & $\begin{array}{c}16 \\
(1.3) \\
\end{array}$ & $\begin{array}{c}37 \\
(1.3) \\
\end{array}$ & $\begin{array}{c}88 \\
(1.4) \\
\end{array}$ & $\begin{array}{c}35 \\
(1.5) \\
\end{array}$ & $1.3 \%$ \\
\hline $\begin{array}{l}\text { Proceeds after listing (\$ mill.) } \\
\text { (Ave. proceeds per new issue) }\end{array}$ & $\begin{array}{l}31,175 \\
(1,247) \\
\end{array}$ & $\begin{array}{l}875 \\
(88)\end{array}$ & $\begin{array}{c}11,174 \\
(698) \\
\end{array}$ & $\begin{array}{l}5,026 \\
(136) \\
\end{array}$ & $\begin{array}{c}48,250 \\
(548) \\
\end{array}$ & $\begin{array}{c}32,051 \\
(916)\end{array}$ & $10.5 \%$ \\
\hline
\end{tabular}

All Firms in German Civil Law Countries 1/1/84 - 5/1/99

Total Number of New Issues -2777

Total Proceeds from New Issues - \$306,541 mill.

Panel D

Scandinavian Civil Law Countries

\begin{tabular}{|c|c|c|c|c|c|c|c|}
\hline & NYSE & Nasdaq & $\overline{\text { OTC }}$ & $144 a$ & Total & Org. Exch & $\begin{array}{l}\text { Percent of all } \\
\text { New Issues }\end{array}$ \\
\hline $\begin{array}{l}\text { Number of Cross-listings } \\
\text { (\% of total) }\end{array}$ & $\begin{array}{c}14 \\
(21 \%)\end{array}$ & $\begin{array}{c}17 \\
(26 \%)\end{array}$ & $\begin{array}{c}21 \\
(32 \%)\end{array}$ & $\begin{array}{c}14 \\
(21 \%)\end{array}$ & $\begin{array}{c}66 \\
(100 \%)\end{array}$ & $\begin{array}{c}31 \\
(47 \%) \\
\end{array}$ & \\
\hline $\begin{array}{l}\text { CLs issuing equity after listing } \\
\text { (\% of cross-listings) }\end{array}$ & $\begin{array}{c}9 \\
(64 \%) \\
\end{array}$ & $\begin{array}{c}9 \\
(53 \%) \\
\end{array}$ & $\begin{array}{c}2 \\
(10 \%) \\
\end{array}$ & $\begin{array}{c}8 \\
(57 \%) \\
\end{array}$ & $\begin{array}{c}28 \\
(42 \%) \\
\end{array}$ & $\begin{array}{c}18 \\
(58 \%) \\
\end{array}$ & \\
\hline $\begin{array}{l}\text { New Issues after listing } \\
\text { (Issues per issuing cross-listing) }\end{array}$ & $\begin{array}{c}17 \\
(1.9)\end{array}$ & $\begin{array}{c}12 \\
(1.3)\end{array}$ & $\begin{array}{c}4 \\
(2.0) \\
\end{array}$ & $\begin{array}{c}11 \\
(1.4)\end{array}$ & $\begin{array}{c}44 \\
(1.6)\end{array}$ & $\begin{array}{c}29 \\
(1.6) \\
\end{array}$ & $4.1 \%$ \\
\hline $\begin{array}{l}\text { Proceeds after listing } \\
\text { (Ave. proceeds per new issue) }\end{array}$ & $\begin{array}{l}8,402 \\
(494)\end{array}$ & $\begin{array}{c}1,064 \\
(89)\end{array}$ & $\begin{array}{c}895 \\
(224)\end{array}$ & $\begin{array}{l}4,575 \\
(416)\end{array}$ & $\begin{array}{c}14,937 \\
(339)\end{array}$ & $\begin{array}{l}9,466 \\
(326)\end{array}$ & $17.4 \%$ \\
\hline
\end{tabular}

All Firms in Scandinavian Civil Law Countries 1/1/84 - 5/1/99

Total Number of New Issues -700

Total Proceeds from New Issues - \$54,551 mill.

\section{Panel E}

Totals

\begin{tabular}{|l|c|c|c|c|c|c|c|}
\hline & NYSE & Nasdaq & OTC & $\mathbf{1 4 4 a}$ & Total & Org. Exch & $\begin{array}{l}\text { Percent of all } \\
\text { New Issues }\end{array}$ \\
\hline $\begin{array}{l}\text { Number of Cross-listings } \\
\text { (\% of total) }\end{array}$ & $\begin{array}{c}385 \\
(20 \%)\end{array}$ & $\begin{array}{c}380 \\
(20 \%)\end{array}$ & $\begin{array}{c}873 \\
(46 \%)\end{array}$ & $\begin{array}{c}274 \\
(14 \%)\end{array}$ & $\begin{array}{c}1912 \\
(100 \%)\end{array}$ & $\begin{array}{c}765 \\
(40 \%)\end{array}$ & \\
\hline $\begin{array}{l}\text { CLs issuing equity after listing } \\
\text { (\% of cross-listings) }\end{array}$ & $\begin{array}{c}172 \\
(45 \%)\end{array}$ & $\begin{array}{c}205 \\
(54 \%)\end{array}$ & $\begin{array}{c}133 \\
(15 \%)\end{array}$ & $\begin{array}{c}134 \\
(49 \%)\end{array}$ & $\begin{array}{c}644 \\
(34 \%)\end{array}$ & $\begin{array}{c}377 \\
(49 \%)\end{array}$ & \\
\hline New Issues after listing & 286 & 284 & 166 & 168 & 904 & 570 & $3.4 \%$ \\
(Issues per issuing cross-listing) & $(1.7)$ & $(1.4)$ & $(1.2)$ & $(1.3)$ & $(1.4)$ & $(1.5)$ & \\
\hline $\begin{array}{l}\text { Proceeds after listing (\$ mill.) } \\
\text { (Ave. proceeds per new issue) }\end{array}$ & $\begin{array}{c}247,957 \\
(867)\end{array}$ & $\begin{array}{c}26,878 \\
(95)\end{array}$ & $\begin{array}{c}32,727 \\
(197)\end{array}$ & $\begin{array}{c}43,019 \\
(256)\end{array}$ & $\begin{array}{c}350,580 \\
(388)\end{array}$ & $\begin{array}{c}274,835 \\
(482)\end{array}$ & $22.2 \%$ \\
\hline
\end{tabular}

All Firms in the four legal systems 1/1/84 - 5/1/99

Total Number of New Issues -16982

Total Proceeds from New Issues - \$1,238,049 mill. 


\section{Table 5}

\section{Multivariate Estimates of New Equity Issues}

This table examines twelve separate multivariate analyses. The first six use Logit while the second six use Tobit with the dependent variable left-censored at zero and the model fit to a normal distribution. Columns 1-6 consider the probability that a foreign company cross listing on an organized U.S. exchange will issue new equity at or after the time of its cross listing conditional on that firm cross-listing on an organized exchange. For columns 7-12, the dependent variable is the proceeds from all of a firm's new equity issues either simultaneously with or subsequent to its cross-listing on an organized U.S. exchange. We examine three separate measures of shareholder protection. The legal tradition explanatory variables (French, German and Scandinavian) are dummy variables taking a value of one if the firm came from a country with that legal tradition and zero otherwise. Since these are the civil law legal traditions, they each measure their difference from firms that come from countries with an English Common Law tradition. The next two explanatory variables are taken from La Porta et. al $(1997,1998)$. The Antidirector Rights variable is an index aggregating six significant shareholder rights. The Accounting Standards variable is an index created by examining and rating companies' 1990 annual reports on their inclusion or omission of 90 items. For these two variables, a higher value means (respectively), greater rights for minority shareholders and tighter accounting standards. These variables are country-specific and are applied to each firm based on its home country. The country new issues variable controls for the total number of new issues in the firm's home country between 1/1/85 and 6/1/99. The IPO dummy is given a value of one if the cross-listing occurs simultaneously with the firm's IPO and zero if the firm already had publicly traded shares. The log of GNP variable is used in each regression to control for the size of the firm's home country. Columns 1-3 and 7-9 use our entire sample of 765 firms that cross list on an organized exchange. Columns 4-6 and 1012 consider the subsample of 377 firms for which we have firm-specific data from Worldscope. They include a variable for the log of the firm's market value to control for the size of the firm. $p$-values appear in parentheses below each coefficient estimate.

\begin{tabular}{|c|c|c|c|c|c|c|c|c|c|c|c|c|}
\hline \multirow{3}{*}{$\begin{array}{c}\text { Explanatory } \\
\text { Variable(s) } \\
\end{array}$} & \multicolumn{6}{|c|}{ Probability of Issuing New Equity } & \multicolumn{6}{|c|}{ Proceeds from Issuing New Equity } \\
\hline & \multicolumn{3}{|c|}{$\begin{array}{c}\text { Full Sample } \\
N=765\end{array}$} & \multicolumn{3}{|c|}{$\begin{array}{c}\text { Worldscope Subsample } \\
\mathbf{N}=\mathbf{3 7 7}\end{array}$} & \multicolumn{3}{|c|}{$\begin{array}{c}\text { Full Sample } \\
N=765\end{array}$} & \multicolumn{3}{|c|}{$\begin{array}{l}\text { Worldscope Subsample } \\
\mathbf{N}=\mathbf{3 7 7}\end{array}$} \\
\hline & $\# 1$ & $\# 2$ & $\# 3$ & $\# 4$ & $\# 5$ & $\# 6$ & $\# 7$ & $\# 8$ & \#9 & $\# 10$ & $\# 11$ & $\# 12$ \\
\hline $\begin{array}{l}\text { French Law } \\
\text { Dummy }\end{array}$ & $\begin{array}{l}-0.081 \\
(.6953)\end{array}$ & & & $\begin{array}{l}0.3223 \\
(.2627)\end{array}$ & & & $\begin{array}{l}692.17 \\
(.0042)\end{array}$ & & & $\begin{array}{l}362.81 \\
(.2624)\end{array}$ & & \\
\hline $\begin{array}{l}\text { German Law } \\
\text { Dummy }\end{array}$ & $\begin{array}{l}0.3393 \\
(.3777)\end{array}$ & & & $\begin{array}{l}0.1721 \\
(.6891)\end{array}$ & & & $\begin{array}{l}637.60 \\
(.1844)\end{array}$ & & & $\begin{array}{l}-183.5 \\
(.7296)\end{array}$ & & \\
\hline $\begin{array}{l}\text { Scandinavian } \\
\text { Law Dummy }\end{array}$ & $\begin{array}{l}0.5735 \\
(.1778) \\
\end{array}$ & & & $\begin{array}{l}0.8371 \\
(.1029) \\
\end{array}$ & & & $\begin{array}{l}848.81 \\
(.1176) \\
\end{array}$ & & & $\begin{array}{l}495.27 \\
(.3920) \\
\end{array}$ & & \\
\hline $\begin{array}{l}\text { Antidirector } \\
\text { Rights }\end{array}$ & & $\begin{array}{l}-0.100 \\
(.1480)\end{array}$ & & & $\begin{array}{l}-0.192 \\
(.0410)\end{array}$ & & & $\begin{array}{l}-258.3 \\
(.0012)\end{array}$ & & & $\begin{array}{l}-178.9 \\
(.0848)\end{array}$ & \\
\hline $\begin{array}{l}\text { Accounting } \\
\text { Standards }\end{array}$ & & & $\begin{array}{l}0.0040 \\
(.7104)\end{array}$ & & & $\begin{array}{l}-0.005 \\
(.7266)\end{array}$ & & & $\begin{array}{l}-28.22 \\
(.0445)\end{array}$ & & & $\begin{array}{l}-9.01 \\
(.5795)\end{array}$ \\
\hline $\begin{array}{l}\text { Country New } \\
\text { Issues }\end{array}$ & $\begin{array}{l}0.0003 \\
(.1185)\end{array}$ & $\begin{array}{l}0.0004 \\
(.0433)\end{array}$ & $\begin{array}{l}0.0003 \\
(.1176)\end{array}$ & $\begin{array}{l}0.0002 \\
(.4741)\end{array}$ & $\begin{array}{l}0.0002 \\
(.3059)\end{array}$ & $\begin{array}{l}0.0001 \\
(.7267)\end{array}$ & $\begin{array}{l}0.0055 \\
(.0294)\end{array}$ & $\begin{array}{l}0.0057 \\
(.0254)\end{array}$ & $\begin{array}{l}0.0057 \\
(.0293)\end{array}$ & $\begin{array}{l}0.0002 \\
(.9451)\end{array}$ & $\begin{array}{l}0.0013 \\
(.6739)\end{array}$ & $\begin{array}{l}0.0005 \\
(.8827)\end{array}$ \\
\hline IPO Dummy & $\begin{array}{l}2.8123 \\
(.0001) \\
\end{array}$ & $\begin{array}{l}2.7238 \\
(.0001) \\
\end{array}$ & $\begin{array}{l}2.7251 \\
(.0001) \\
\end{array}$ & $\begin{array}{l}2.0481 \\
(.0001) \\
\end{array}$ & $\begin{array}{l}1.9945 \\
(.0001) \\
\end{array}$ & $\begin{array}{l}2.0446 \\
(.0001) \\
\end{array}$ & $\begin{array}{l}2263.4 \\
(.0001) \\
\end{array}$ & $\begin{array}{l}2043.9 \\
(.0001) \\
\end{array}$ & $\begin{array}{l}2184.9 \\
(.0001) \\
\end{array}$ & $\begin{array}{l}1977.9 \\
(.0001) \\
\end{array}$ & $\begin{array}{l}1925.3 \\
(.0001) \\
\end{array}$ & $\begin{array}{l}1999.6 \\
(.0001) \\
\end{array}$ \\
\hline $\begin{array}{l}\text { Log of Market } \\
\text { Value }\end{array}$ & & & & $\begin{array}{l}-0.084 \\
(.2172)\end{array}$ & $\begin{array}{l}-0.080 \\
(.2281)\end{array}$ & $\begin{array}{l}-0.051 \\
(.4464)\end{array}$ & & & & $\begin{array}{l}328.42 \\
(.0001)\end{array}$ & $\begin{array}{l}327.06 \\
(.0001)\end{array}$ & $\begin{array}{l}346.98 \\
(.0001)\end{array}$ \\
\hline Log of GNP & $\begin{array}{l}-0.254 \\
(.0086) \\
\end{array}$ & $\begin{array}{l}-0.248 \\
(.0067) \\
\end{array}$ & $\begin{array}{l}-0.271 \\
(.0053) \\
\end{array}$ & $\begin{array}{l}-0.150 \\
(.2547) \\
\end{array}$ & $\begin{array}{l}-0.197 \\
(.1056) \\
\end{array}$ & $\begin{array}{l}-0.207 \\
(.1084) \\
\end{array}$ & $\begin{array}{l}-72.33 \\
(.6148) \\
\end{array}$ & $\begin{array}{c}-45.89 \\
(.7389) \\
\end{array}$ & $\begin{array}{c}1.71 \\
(.9907) \\
\end{array}$ & $\begin{array}{c}-12.04 \\
(.9485) \\
\end{array}$ & $\begin{array}{c}-108.6 \\
(.5306) \\
\end{array}$ & $\begin{array}{l}-112.7 \\
(.5312) \\
\end{array}$ \\
\hline Log-Likelihood & -530 & -530 & -515 & -260 & -260 & -256 & -3623 & -3623 & -3527 & -1722 & -1721 & -1703 \\
\hline
\end{tabular}




\section{Table 6 \\ Equity Issues by Location of Issuance}

In this table, each panel looks at one of the four major legal systems. We look at foreign firms that were cross-listed in the U.S. in June 1999 and that issued new equity either simultaneously with or after their cross-listing. The table separates the number of equity issues and proceeds by whether the capital was raised in the U.S., the country's home market, or elsewhere. In counting the number of issues, each issuance at a different location is counted as a separate issue. For example, if a firm issues equity simultaneously in its home market and in the U.S., we would count that as two separate issuances. The first four columns organize the issues and proceeds by the exchange that the cross-listed firm trades on. The fifth column totals the first four, and column six is the total of the NYSE and Nasdaq columns. This is significant since these are the exchanges that require specific accounting and disclosure information in order for a firm to cross-list on it. Values in parenthesis are percentages of the total for each exchange.

\section{Panel A}

\section{English Common Law Countries}

\begin{tabular}{|c|c|c|c|c|c|c|c|}
\hline & & NYSE & Nasdaq & OTC & $144 a$ & $\begin{array}{c}\text { All } \\
\text { Exchanges }\end{array}$ & $\begin{array}{l}\text { Organized } \\
\text { Exchanges }\end{array}$ \\
\hline \multirow{4}{*}{$\begin{array}{l}\text { Number of } \\
\text { Equity Issues } \\
\text { (Percent of } \\
\text { Total) }\end{array}$} & In U.S. & $\begin{array}{c}83 \\
(56.8 \%) \\
\end{array}$ & $\begin{array}{c}191 \\
(70.0 \%) \\
\end{array}$ & $\begin{array}{c}22 \\
(16.5 \%) \\
\end{array}$ & $\begin{array}{c}0 \\
(0.0 \%) \\
\end{array}$ & $\begin{array}{c}296 \\
(48.8 \%) \\
\end{array}$ & $\begin{array}{c}274 \\
(65.4 \%) \\
\end{array}$ \\
\hline & At Home & $\begin{array}{c}19 \\
(13.0 \%) \\
\end{array}$ & $\begin{array}{c}29 \\
(10.6 \%) \\
\end{array}$ & $\begin{array}{c}73 \\
(54.9 \%) \\
\end{array}$ & $\begin{array}{c}16 \\
(29.6 \%) \\
\end{array}$ & $\begin{array}{c}137 \\
(22.6 \%) \\
\end{array}$ & $\begin{array}{c}48 \\
(11.5 \%) \\
\end{array}$ \\
\hline & Elsewhere & $\begin{array}{c}44 \\
(30.1 \%) \\
\end{array}$ & $\begin{array}{c}53 \\
(19.4 \%) \\
\end{array}$ & $\begin{array}{c}38 \\
(28.6 \%) \\
\end{array}$ & $\begin{array}{c}38 \\
(70.4 \%) \\
\end{array}$ & $\begin{array}{c}173 \\
(28.5 \%) \\
\end{array}$ & $\begin{array}{c}97 \\
(23.2 \%) \\
\end{array}$ \\
\hline & Total & 146 & 273 & 133 & 54 & 606 & 419 \\
\hline \multirow{4}{*}{$\begin{array}{l}\text { Proceeds from } \\
\text { Equity Issues } \\
\text { (\$ mill.) } \\
\text { (Percent of } \\
\text { Total) }\end{array}$} & In U.S. & $\begin{array}{c}18,168 \\
(31.7 \%) \\
\end{array}$ & $\begin{array}{c}9,694 \\
(55.1 \%) \\
\end{array}$ & $\begin{array}{c}563 \\
(4.1 \%) \\
\end{array}$ & $\begin{array}{c}0 \\
(0.0 \%) \\
\end{array}$ & $\begin{array}{c}28,425 \\
(28.3 \%) \\
\end{array}$ & $\begin{array}{c}27,862 \\
(37.2 \%) \\
\end{array}$ \\
\hline & At Home & $\begin{array}{c}24,837 \\
(43.3 \%) \\
\end{array}$ & $\begin{array}{c}3,456 \\
(19.6 \%) \\
\end{array}$ & $\begin{array}{c}8,802 \\
(64.3 \%) \\
\end{array}$ & $\begin{array}{c}6,884 \\
(57.9 \%) \\
\end{array}$ & $\begin{array}{c}43,979 \\
(43.7 \%) \\
\end{array}$ & $\begin{array}{c}28,293 \\
(37.7 \%) \\
\end{array}$ \\
\hline & Elsewhere & $\begin{array}{c}14,365 \\
(25.0 \%) \\
\end{array}$ & $\begin{array}{c}4,455 \\
(25.3 \%) \\
\end{array}$ & $\begin{array}{c}4,316 \\
(31.5 \%) \\
\end{array}$ & $\begin{array}{c}5,010 \\
(42.1 \%) \\
\end{array}$ & $\begin{array}{c}28,146 \\
(28.0 \%) \\
\end{array}$ & $\begin{array}{c}18,820 \\
(25.1 \%) \\
\end{array}$ \\
\hline & Total & 57,370 & 17,605 & 13,681 & 11,894 & 100,550 & 74,975 \\
\hline
\end{tabular}

\section{Panel B}

\section{French Civil Law Countries}

\begin{tabular}{|c|c|c|c|c|c|c|c|}
\hline & & NYSE & Nasdaq & OTC & $144 a$ & $\begin{array}{c}\text { All } \\
\text { Exchanges }\end{array}$ & $\begin{array}{l}\text { Organized } \\
\text { Exchanges }\end{array}$ \\
\hline \multirow{4}{*}{$\begin{array}{l}\text { Number of } \\
\text { Equity Issues } \\
\text { (Percent of } \\
\text { Total) }\end{array}$} & In U.S. & $\begin{array}{c}108 \\
(34.2 \%) \\
\end{array}$ & $\begin{array}{c}44 \\
(47.8 \%) \\
\end{array}$ & $\begin{array}{c}4 \\
(10.5 \%) \\
\end{array}$ & $\begin{array}{c}1 \\
(0.9 \%) \\
\end{array}$ & $\begin{array}{c}157 \\
(28.4 \%) \\
\end{array}$ & $\begin{array}{c}152 \\
(37.3 \%) \\
\end{array}$ \\
\hline & At Home & $\begin{array}{c}105 \\
(33.2 \%) \\
\end{array}$ & $\begin{array}{c}13 \\
(14.1 \%) \\
\end{array}$ & $\begin{array}{c}21 \\
(55.3 \%) \\
\end{array}$ & $\begin{array}{c}60 \\
(56.6 \%) \\
\end{array}$ & $\begin{array}{c}199 \\
(36.1 \%) \\
\end{array}$ & $\begin{array}{c}118 \\
(28.9 \%) \\
\end{array}$ \\
\hline & Elsewhere & $\begin{array}{c}103 \\
(32.6 \%)\end{array}$ & $\begin{array}{c}35 \\
(38.0 \%)\end{array}$ & $\begin{array}{c}13 \\
(34.2 \%)\end{array}$ & $\begin{array}{c}45 \\
(42.5 \%)\end{array}$ & $\begin{array}{c}196 \\
(35.5 \%)\end{array}$ & $\begin{array}{c}138 \\
(33.8 \%)\end{array}$ \\
\hline & Total & 316 & 92 & 38 & 106 & 552 & 408 \\
\hline \multirow{4}{*}{$\begin{array}{l}\text { Proceeds from } \\
\text { Equity Issues } \\
\text { (\$ mill.) } \\
\text { (Percent of } \\
\text { Total) }\end{array}$} & In U.S. & $\begin{array}{c}27,059 \\
(17.9 \%) \\
\end{array}$ & $\begin{array}{c}3,106 \\
(42.4 \%) \\
\end{array}$ & $\begin{array}{c}285 \\
(4.1 \%) \\
\end{array}$ & $\begin{array}{c}120 \\
(0.6 \%) \\
\end{array}$ & $\begin{array}{c}30,570 \\
(16.4 \%) \\
\end{array}$ & $\begin{array}{c}30,165 \\
(19.1 \%) \\
\end{array}$ \\
\hline & At Home & $\begin{array}{c}90,739 \\
(60.1 \%) \\
\end{array}$ & $\begin{array}{c}1,182 \\
(16.1 \%) \\
\end{array}$ & $\begin{array}{c}4,734 \\
(67.9 \%) \\
\end{array}$ & $\begin{array}{c}13,072 \\
(60.7 \%) \\
\end{array}$ & $\begin{array}{l}109,727 \\
(58.7 \%) \\
\end{array}$ & $\begin{array}{c}91,921 \\
(58.1 \%) \\
\end{array}$ \\
\hline & Elsewhere & $\begin{array}{c}33,212 \\
(22.0 \%)\end{array}$ & $\begin{array}{c}3,046 \\
(41.5 \%)\end{array}$ & $\begin{array}{c}1,957 \\
(28.1 \%)\end{array}$ & $\begin{array}{c}8,331 \\
(38.7 \%)\end{array}$ & $\begin{array}{c}46,546 \\
(24.9 \%)\end{array}$ & $\begin{array}{c}36,258 \\
(22.9 \%)\end{array}$ \\
\hline & Total & 151,010 & 7,334 & 6,976 & 21,523 & 186,843 & 158,344 \\
\hline
\end{tabular}




\section{Panel C}

German Civil Law Countries

\begin{tabular}{|c|c|c|c|c|c|c|c|}
\hline & & NYSE & Nasdaq & OTC & $144 a$ & $\begin{array}{c}\text { All } \\
\text { Exchanges }\end{array}$ & $\begin{array}{l}\text { Organized } \\
\text { Exchanges }\end{array}$ \\
\hline \multirow{4}{*}{$\begin{array}{l}\text { Number of } \\
\text { Equity Issues } \\
\text { (Percent of } \\
\text { Total) }\end{array}$} & In U.S. & $\begin{array}{c}17 \\
(37.0 \%)\end{array}$ & $\begin{array}{c}8 \\
(53.3 \%)\end{array}$ & $\begin{array}{c}0 \\
(0.0 \%)\end{array}$ & $\begin{array}{c}0 \\
(0.0 \%)\end{array}$ & $\begin{array}{c}25 \\
(20.5 \%)\end{array}$ & $\begin{array}{c}25 \\
(41.0 \%) \\
\end{array}$ \\
\hline & At Home & $\begin{array}{c}9 \\
(19.6 \%)\end{array}$ & $\begin{array}{c}3 \\
(20.0 \%)\end{array}$ & $\begin{array}{c}13 \\
(61.9 \%)\end{array}$ & $\begin{array}{c}4 \\
(10.0 \%)\end{array}$ & $\begin{array}{c}29 \\
(23.8 \%)\end{array}$ & $\begin{array}{c}12 \\
(19.7 \%)\end{array}$ \\
\hline & Elsewhere & $\begin{array}{c}20 \\
(43.5 \%) \\
\end{array}$ & $\begin{array}{c}4 \\
(26.7 \%) \\
\end{array}$ & $\begin{array}{c}8 \\
(38.1 \%) \\
\end{array}$ & $\begin{array}{c}36 \\
(90.0 \%) \\
\end{array}$ & $\begin{array}{c}68 \\
(55.7 \%) \\
\end{array}$ & $\begin{array}{c}24 \\
(39.3 \%) \\
\end{array}$ \\
\hline & Total & 46 & 15 & 21 & 40 & 122 & 61 \\
\hline \multirow{4}{*}{$\begin{array}{l}\text { Proceeds from } \\
\text { Equity Issues } \\
\text { (\$ mill.) } \\
\text { (Percent of } \\
\text { Total) }\end{array}$} & In U.S. & $\begin{array}{c}8,032 \\
(25.8 \%)\end{array}$ & $\begin{array}{c}523 \\
(59.8 \%)\end{array}$ & $\begin{array}{c}0 \\
(0.0 \%)\end{array}$ & $\begin{array}{c}0 \\
(0.0 \%)\end{array}$ & $\begin{array}{c}8,555 \\
(17.7 \%)\end{array}$ & $\begin{array}{c}8,555 \\
(26.7 \%)\end{array}$ \\
\hline & At Home & $\begin{array}{c}15,433 \\
(49.5 \%)\end{array}$ & $\begin{array}{c}151 \\
(17.3 \%)\end{array}$ & $\begin{array}{c}8,615 \\
(77.1 \%)\end{array}$ & $\begin{array}{c}962 \\
(19.1 \%)\end{array}$ & $\begin{array}{c}25,161 \\
(52.1 \%)\end{array}$ & $\begin{array}{c}15,584 \\
(48.6 \%)\end{array}$ \\
\hline & Elsewhere & $\begin{array}{c}7,710 \\
(24.7 \%)\end{array}$ & $\begin{array}{c}201 \\
(23.0 \%)\end{array}$ & $\begin{array}{c}2,558 \\
(22.9 \%)\end{array}$ & $\begin{array}{c}4,064 \\
(80.9 \%)\end{array}$ & $\begin{array}{c}14,533 \\
(30.1 \%)\end{array}$ & $\begin{array}{c}7,911 \\
(24.7 \%)\end{array}$ \\
\hline & Total & 31,175 & 875 & 11,173 & 5,026 & 48,249 & 32,050 \\
\hline
\end{tabular}

\section{Panel D}

\section{Scandinavian Civil Law Countries}

\begin{tabular}{|c|c|c|c|c|c|c|c|}
\hline & & NYSE & Nasdaq & OTC & $144 a$ & $\begin{array}{c}\text { All } \\
\text { Exchanges } \\
\end{array}$ & $\begin{array}{l}\text { Organized } \\
\text { Exchanges } \\
\end{array}$ \\
\hline \multirow{4}{*}{$\begin{array}{l}\text { Number of } \\
\text { Equity Issues } \\
\text { (Percent of } \\
\text { Total) }\end{array}$} & In U.S. & $\begin{array}{c}14 \\
(43.8 \%)\end{array}$ & $\begin{array}{c}7 \\
(38.9 \%)\end{array}$ & $\begin{array}{c}0 \\
(0.0 \%)\end{array}$ & $\begin{array}{c}0 \\
(0.0 \%)\end{array}$ & $\begin{array}{c}21 \\
(28.8 \%) \\
\end{array}$ & $\begin{array}{c}21 \\
(42.0 \%)\end{array}$ \\
\hline & At Home & $\begin{array}{c}9 \\
(28.1 \%)\end{array}$ & $\begin{array}{c}5 \\
(27.8 \%)\end{array}$ & $\begin{array}{c}2 \\
(50.0 \%)\end{array}$ & $\begin{array}{c}10 \\
(52.6 \%)\end{array}$ & $\begin{array}{c}26 \\
(35.6 \%)\end{array}$ & $\begin{array}{c}14 \\
(28.0 \%)\end{array}$ \\
\hline & Elsewhere & $\begin{array}{c}9 \\
(28.1 \%) \\
\end{array}$ & $\begin{array}{c}6 \\
(33.3 \%) \\
\end{array}$ & $\begin{array}{c}2 \\
(50.0 \%) \\
\end{array}$ & $\begin{array}{c}9 \\
(47.4 \%) \\
\end{array}$ & $\begin{array}{c}26 \\
(35.6 \%) \\
\end{array}$ & $\begin{array}{c}15 \\
(30.0 \%) \\
\end{array}$ \\
\hline & Total & 32 & 18 & 4 & 19 & 73 & 50 \\
\hline \multirow{4}{*}{$\begin{array}{l}\text { Proceeds from } \\
\text { Equity Issues } \\
\text { (\$ mill.) } \\
\text { (Percent of } \\
\text { Total) }\end{array}$} & In U.S. & $\begin{array}{c}3,128 \\
(37.2 \%)\end{array}$ & $\begin{array}{c}308 \\
(28.9 \%)\end{array}$ & $\begin{array}{c}0 \\
(0.0 \%)\end{array}$ & $\begin{array}{c}0 \\
(0.0 \%)\end{array}$ & $\begin{array}{c}3,436 \\
(23.0 \%)\end{array}$ & $\begin{array}{c}3,436 \\
(36.3 \%)\end{array}$ \\
\hline & At Home & $\begin{array}{c}3,048 \\
(36.3 \%)\end{array}$ & $\begin{array}{c}409 \\
(38.4 \%)\end{array}$ & $\begin{array}{c}28 \\
(3.1 \%)\end{array}$ & $\begin{array}{c}2064 \\
(45.1 \%)\end{array}$ & $\begin{array}{c}5,549 \\
(37.1 \%)\end{array}$ & $\begin{array}{c}3,457 \\
(36.5 \%)\end{array}$ \\
\hline & Elsewhere & $\begin{array}{c}2,227 \\
(26.5 \%)\end{array}$ & $\begin{array}{c}347 \\
(32.6 \%)\end{array}$ & $\begin{array}{c}867 \\
(96.9 \%)\end{array}$ & $\begin{array}{c}2,511 \\
(54.9 \%)\end{array}$ & $\begin{array}{c}5,952 \\
(39.8 \%)\end{array}$ & $\begin{array}{c}2,574 \\
(27.2 \%)\end{array}$ \\
\hline & Total & 8,403 & 1,064 & 895 & 4,575 & 14,937 & 9,467 \\
\hline
\end{tabular}


Table 7

\section{Multivariate Estimates of Equity Issuances Outside the U.S.}

This table examines twelve separate multivariate analyses. The first six use Logit while the second six use Tobit with the dependent variable left-censored at zero and the model fit to a normal distribution. Columns 1-6 consider the probability that a foreign company cross listing on an organized U.S. exchange will issue new equity outside the U.S. at or after the time of its cross-listing (conditional on its decision to issue new equity). In each analysis, the dependent variable takes on a value of 1 if the equity is issued outside the U.S. and 0 if it is issued in the U.S. For columns 7-12, the dependent variable is the proportion of proceeds from all of a firm's new issues that were placed outside the U.S. (conditional on the firm cross-listing on a organized exchange and either simultaneously or subsequently issuing new equity). We examine three separate measures of shareholder protection. The legal tradition explanatory variables (French, German and Scandinavian) are dummy variables taking a value of one if the firm came from a country with that legal tradition and zero otherwise. Since these are the civil law legal traditions, they each measure their difference from firms that come from countries with an English Common Law tradition. The next two explanatory variables are taken from La Porta et. al $(1997,1998)$. The Antidirector Rights variable is an index aggregating six significant shareholder rights. The Accounting Standards variable is an index created by examining and rating companies' 1990 annual reports on their inclusion or omission of 90 items. For these two variables, a higher value means (respectively), greater rights for minority shareholders and tighter accounting standards. These variables are country-specific and are applied to each firm based on its home country. The IPO dummy is given a value of one if the cross-listing occurs simultaneously with the firm's IPO and zero if the firm already had publicly traded shares. The $\log$ of GNP variable is used in each regression to control for the size of the firm's home country. Columns 1-3 and 7-9 use our entire sample of firms that cross list on an organized exchange. There are 372 firms that issued equity a total of 937 times. Columns 4-6 and 10-12 consider the subsample of firms for which we have firm-specific data from Worldscope. They include a variable for the log of the firm's market value to control for the size of the firm. $p$-values appear in parentheses below each coefficient estimate.

\begin{tabular}{|c|c|c|c|c|c|c|c|c|c|c|c|c|}
\hline \multirow{3}{*}{$\begin{array}{c}\text { Explanatory } \\
\text { Variable(s) }\end{array}$} & \multicolumn{6}{|c|}{ Probability of Issuing Equity Outside the U.S. } & \multicolumn{6}{|c|}{ Proportion of Equity Proceeds Outside the U.S. } \\
\hline & \multicolumn{3}{|c|}{$\begin{array}{c}\text { Full Sample } \\
\mathbf{N}=937 \\
\end{array}$} & \multicolumn{3}{|c|}{$\begin{array}{c}\text { Worldscope Subsample } \\
\text { N=538 } \\
\end{array}$} & \multicolumn{3}{|c|}{$\begin{array}{c}\begin{array}{c}\text { Full Sample } \\
\mathrm{N}=372\end{array} \\
\end{array}$} & \multicolumn{3}{|c|}{$\begin{array}{c}\text { Worldscope Subsample } \\
\mathrm{N}=177\end{array}$} \\
\hline & $\# 1$ & $\# 2$ & \#3 & $\# 4$ & $\# 5$ & $\# 6$ & $\# 7$ & $\# 8$ & $\# 9$ & $\# 10$ & $\# 11$ & $\# 12$ \\
\hline $\begin{array}{l}\text { French Law } \\
\text { Dummy }\end{array}$ & $\begin{array}{l}1.1600 \\
(.0001)\end{array}$ & & & $\begin{array}{l}0.7560 \\
(.0002)\end{array}$ & & & $\begin{array}{l}0.5416 \\
(.0001)\end{array}$ & & & $\begin{array}{l}0.2928 \\
(.0001) \\
\end{array}$ & & \\
\hline $\begin{array}{l}\text { German Law } \\
\text { Dummy }\end{array}$ & $\begin{array}{l}0.8541 \\
(.0034)\end{array}$ & & & $\begin{array}{l}0.4768 \\
(.2102)\end{array}$ & & & $\begin{array}{l}0.3758 \\
(.0009)\end{array}$ & & & $\begin{array}{l}0.1155 \\
(.3697) \\
\end{array}$ & & \\
\hline $\begin{array}{l}\text { Scandinavian } \\
\text { Law Dummy }\end{array}$ & $\begin{array}{l}0.9833 \\
(.0017)\end{array}$ & & & $\begin{array}{l}0.6033 \\
(.0899)\end{array}$ & & & $\begin{array}{l}0.5142 \\
(.0001)\end{array}$ & & & $\begin{array}{l}0.3200 \\
(.0117)\end{array}$ & & \\
\hline $\begin{array}{l}\text { Antidirector } \\
\text { Rights }\end{array}$ & & $\begin{array}{l}-0.192 \\
(.0001)\end{array}$ & & & $\begin{array}{l}-0.148 \\
(.0212) \\
\end{array}$ & & & $\begin{array}{l}-0.105 \\
(.0001) \\
\end{array}$ & & & $\begin{array}{l}-0.049 \\
(.0413) \\
\end{array}$ & \\
\hline $\begin{array}{l}\text { Accounting } \\
\text { Standards }\end{array}$ & & & $\begin{array}{r}-0.039 \\
(.0001) \\
\end{array}$ & & & $\begin{array}{l}-0.018 \\
(.0864)\end{array}$ & & & $\begin{array}{l}-0.019 \\
(.0001)\end{array}$ & & & $\begin{array}{l}-0.0055 \\
(.1630) \\
\end{array}$ \\
\hline IPO Dummy & $\begin{array}{l}-0.224 \\
(.1150) \\
\end{array}$ & $\begin{array}{l}-0.303 \\
(.0294) \\
\end{array}$ & $\begin{array}{l}-0.2638 \\
(.0578) \\
\end{array}$ & $\begin{array}{l}0.2201 \\
(.2373) \\
\end{array}$ & $\begin{array}{l}0.2492 \\
(.1765) \\
\end{array}$ & $\begin{array}{l}0.2319 \\
(.2111) \\
\end{array}$ & $\begin{array}{l}-0.3010 \\
(.0001) \\
\end{array}$ & $\begin{array}{l}-0.346 \\
(.0335) \\
\end{array}$ & $\begin{array}{l}-0.316 \\
(.0001)\end{array}$ & $\begin{array}{l}-0.035 \\
(.6077) \\
\end{array}$ & $\begin{array}{l}-0.016 \\
(.8277) \\
\end{array}$ & $\begin{array}{l}-0.0121 \\
(.8647) \\
\end{array}$ \\
\hline $\begin{array}{l}\text { Log of Market } \\
\text { Value }\end{array}$ & & & & $\begin{array}{l}0.1167 \\
(.0299) \\
\end{array}$ & $\begin{array}{l}0.1525 \\
(.0039) \\
\end{array}$ & $\begin{array}{l}0.1449 \\
(.0064) \\
\end{array}$ & & & & $\begin{array}{l}0.0658 \\
(.0006) \\
\end{array}$ & $\begin{array}{l}0.0787 \\
(.0001) \\
\end{array}$ & $\begin{array}{l}0.0805 \\
(.0001) \\
\end{array}$ \\
\hline Log of GNP & $\begin{array}{l}0.0975 \\
(.1279) \\
\end{array}$ & $\begin{array}{l}0.1190 \\
(.0466) \\
\end{array}$ & $\begin{array}{l}0.2573 \\
(.0196) \\
\end{array}$ & $\begin{array}{l}0.0168 \\
(.8524) \\
\end{array}$ & $\begin{array}{l}-0.052 \\
(.5348) \\
\end{array}$ & $\begin{array}{l}0.0034 \\
(.9737) \\
\end{array}$ & $\begin{array}{l}0.0391 \\
(.1086)\end{array}$ & $\begin{array}{l}0.0546 \\
(.0335) \\
\end{array}$ & $\begin{array}{l}0.1161 \\
(.0001)\end{array}$ & $\begin{array}{l}0.0350 \\
(.2793)\end{array}$ & $\begin{array}{l}-0.001 \\
(.9950)\end{array}$ & $\begin{array}{l}0.0143 \\
(.6929)\end{array}$ \\
\hline Log-Likelihood & -640 & -640 & -623 & -358 & -358 & -353 & -265 & -298 & -290 & -123 & -129 & -127 \\
\hline
\end{tabular}


